\title{
Antibiotic-resistance in medically important bacteria isolated from commercial herbal medicines in Africa from 2000 to 2021: a systematic review and meta-analysis
}

\author{
Abdul Walusansa ${ }^{1,2,4^{*}} \mathbb{D}$, Savina Asiimwe' ${ }^{1}$ Jesca. L. Nakavuma³, Jamilu. E. Ssenku', Esther Katuura', \\ Hussein. M. Kafeero ${ }^{2}$, Dickson Aruhomukama ${ }^{5}$, Alice Nabatanzi ${ }^{1}$, Godwin Anywar ${ }^{1}$, Arthur K. Tugume ${ }^{1}$ and \\ Esezah K. Kakudidi ${ }^{1}$
}

\begin{abstract}
Background: Antimicrobial resistance is swiftly increasing all over the world. In Africa, it manifests more in pathogenic bacteria in form of antibiotic resistance (ABR). On this continent, bacterial contamination of commonly used herbal medicine (HM) is on the increase, but information about antimicrobial resistance in these contaminants is limited due to fragmented studies. Here, we analyzed research that characterized ABR in pathogenic bacteria isolated from HM in Africa since 2000; to generate a comprehensive understanding of the drug-resistant bacterial contamination burden in this region.

Methods: The study was conducted according to standards of the Preferred Reporting Items for Systematic Reviews and Meta-analyses (PRISMA). We searched for articles from 12 databases. These were: PubMed, Science Direct, Scifinder scholar, Google scholar, HerbMed, Medline, EMBASE, Cochrane Library, International Pharmaceutical Abstracts, Commonwealth Agricultural Bureau Abstracts, African Journal Online, and Biological Abstracts. Prevalence and ABR traits of bacterial isolates, Cochran's Q test, and the $\mathrm{I}^{2}$ statistic for heterogeneity were evaluated using MedCalcs software. A random-effects model was used to determine the pooled prevalence of ABR traits. The potential sources of heterogeneity were examined through sensitivity analysis, subgroup analysis, and meta-regression at a 95\% level of significance.

Findings: Eighteen studies met our inclusion criteria. The pooled prevalence of bacterial resistance to at least one conventional drug was $86.51 \%(95 \% \mathrm{Cl}=61.247-99.357 \%)$. The studies were highly heterogeneous $\left(R^{2}=99.17 \%\right.$; $p<0.0001$ ), with no evidence of publication bias. The most prevalent multidrug-resistant species was Escherichia coli (24.0\%). The most highly resisted drug was Ceftazidime with a pooled prevalence of $95.10 \%(95 \% \mathrm{Cl}=78.51-99.87 \%)$, while the drug-class was $3^{\text {rd }}$ generation cephalosporins; $91.64 \%$ (95\% Cl=78.64-96.73\%). None of the eligible studies tested isolates for Carbapenem resistance. Extended Spectrum $\beta$-lactamase genes were detected in 89 (37.2\%) isolates, mostly Salmonella spp., Proteus vulgaris, and K. pneumonia. Resistance plasmids were found in $6(5.8 \%)$ isolates; the heaviest plasmid weighed 23,130 Kilobases, and Proteus vulgaris harbored the majority $(n=5 ; 83.3 \%)$.
\end{abstract}

*Correspondence: abdulwalusansa@gmail.com

${ }^{1}$ Department of Plant Sciences, Microbiology and Biotechnology, School

of Biosciences, Makerere University, Kampala, Uganda

Full list of author information is available at the end of the article

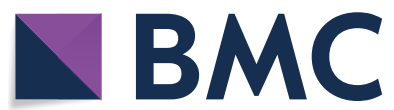

(c) The Author(s) 2022. Open Access This article is licensed under a Creative Commons Attribution 4.0 International License, which permits use, sharing, adaptation, distribution and reproduction in any medium or format, as long as you give appropriate credit to the original author(s) and the source, provide a link to the Creative Commons licence, and indicate if changes were made. The images or other third party material in this article are included in the article's Creative Commons licence, unless indicated otherwise in a credit line to the material. If material is not included in the article's Creative Commons licence and your intended use is not permitted by statutory regulation or exceeds the permitted use, you will need to obtain permission directly from the copyright holder. To view a copy of this licence, visit http://creativecommons.org/licenses/by/4.0/. The Creative Commons Public Domain Dedication waiver (http://creativeco mmons.org/publicdomain/zero/1.0/) applies to the data made available in this article, unless otherwise stated in a credit line to the data. 
Conclusions: Herbal medicines in Africa harbor bacterial contaminants which are highly resistant to conventional medicines. This points to a potential treatment failure when these contaminants are involved in diseases causation. More research on this subject is recommended, to fill the evidence gaps and support the formation of collaborative quality control mechanisms for the herbal medicine industry in Africa.

Keywords: Africa, Antimicrobial resistance, Bacterial contamination, Herbal medicine, Meta-analysis, Systematic review

\section{Background}

Antimicrobial resistance (AMR), is the ability of bacteria, viruses, fungi, and parasites to evade the medicinal activity of drugs to which they were once susceptible [1]. The AMR makes effective treatment difficult or impossible. The major consequences include; increased cost of health care, prolonged hospital stays, and escalation of morbidity and mortality [2]. Currently, AMR causes over 700,000 global annual deaths, and the burden is intensifying rapidly worldwide $[3,4]$. The widespread use of antibiotics, more so under inappropriate prescription in Africa, makes antibiotic resistance (ABR) a predominant form of AMR [5]; and the rates of antibiotic resistance are already alarming in some bacteria, such as Escherichia coli, Klebsiella pneumonia, Salmonella spp., Acinetobacter baumannii, and Staphylococcus aureus [4-12]. These pathogens may spread from infected humans and/or animals to the environmental reservoirs such as; plants, water, soil, and subsequently to the rest of the community in a continuous cycle [the one health concept] [13]. Though often neglected, the potential role of herbal medicine (HM), given its widespread use, is intensifying the burden of ABR and necessitates substantive redress [14].

Globally, the prevalence of $\mathrm{HM}$ use ranges between 50 and $95 \%$, and it is projected to rise with a compound growth rate of $5.5 \%$ by the year $2027[15,16]$. In subSaharan Africa, the rate of HM consumption is reported to be over $60 \%$ [17], and it is used to treat and/or prevent health complications that range from instant emergencies, such as snakebite envenomation, to chronic conditions like; cancer, diabetes, HIV/AIDS-related symptoms, infertility, ulcers, and kidney diseases among others [17-21]. Bacterial pathogens have been documented as major contaminants that may be disseminated in herbal medicines and related products [22, 23]. Consequently, research and case reports concerning the profiles of bacteria that contaminate HM have been published, and their findings have been examined in some scientific reviews [22, 24-28]. In Europe, recent systematic reviews documented Salmonella spp., Escherichia coli, Clostridium perfringens, and Listeria monocytogenes among the frequently reported contaminants of commercial HM $[25,28]$. Bacterial diseases associated with the consumption of contaminated HM were also diagnosed in the population in Europe [25]. However, the drug resistance traits of these pathogenic contaminants were not elucidated. In South Africa, bacteria, such as; Pseudomonas spp., Salmonella spp., Acinetobacter baumannii, Klebsiella pneumoniae, and Staphylococcus aureus, that are capable of impairing human health have been reported in commercial medicinal herbal products [29]. The Staphylococcus aureus exhibited resistance to some of the conventional antibacterial drugs tested such as Methicillin and Vancomycin. Additionally, bacterial toxins such as Bacillus cereus diarrheal toxin have also been reported [29].

The contamination of HM with bacteria (which may be drug-resistant), raises concerns related to the community spread of antibiotic resistance. Though some researchers have continued to examine the loads and diversity of bacteria that contaminate HM in Africa, there is a shortage of comprehensive, continent-wide, scientific evidence, to explain the drug resistance patterns, and the genetic basis of resistance in these bacteria. This hinders the design of concerted herbal safety interventions and AMR stewardship programs on the continent. Therefore, this systematic review examined the original research articles related to drug resistance phenotypes, and the genes mediating this resistance, in potentially pathogenic bacteria that have been reported to contaminate $\mathrm{HM}$ in Africa in the past two decades. The rationale was to inform the design of collaborative approaches to support African countries in combating antimicrobial resistance.

\section{Materials and methods \\ Study area}

This meta-analysis included all the 54 countries that are located in the African region, as described by United Nations [30].

\section{Search strategy}

Relevant key terms were used (initially used singly and later combined via linking words like, "with", "and", "or", "plus"), to search twelve electronic databases (Table 1), for published articles relating to drug-resistant bacterial contamination of herbal medicine in the 54 countries 
Table 1 Databases searched, and the search terms used to identify publications on drug-resistant bacterial contamination of herbal medicines in Africa since 2000

\begin{tabular}{|c|c|}
\hline Databases searched & Search terms \\
\hline $\begin{array}{l}\text { PubMed, Science Direct, Scifinder Scholar, Google scholar, HerbMed, } \\
\text { Medline, EMBASE, Cochrane Library, International Pharmaceutical } \\
\text { Abstracts, Commonwealth Agricultural Bureau Abstracts, Biological } \\
\text { Abstracts, African Journal Online (AJOL) }\end{array}$ & $\begin{array}{l}\text { Herbal medicine, Indigenous traditional medicine, Microbial herbal con- } \\
\text { tamination, bacterial herbal contamination, Herbal medicine safety, Herbal } \\
\text { medicine risks, Bacteria, Bacterial drug resistance, Bacterial drug resistance } \\
\text { genes, Africa, Uganda, Nigeria, Ethiopia, Egypt, Democratic Republic of } \\
\text { Congo, Tanzania, South Africa, Kenya, Algeria, Sudan, Morocco, Angola, } \\
\text { Mozambique, Ghana, Madagascar, Cameroon, Cote d'Ivoire, Niger, Burkina } \\
\text { Faso, Mali, Malawi, Zambia, Senegal, Chad, Somalia, Zimbabwe, Guinea, } \\
\text { Rwanda, Benin, Burundi, Tunisia, South Sudan, Togo, Sierra Leon, Libya, } \\
\text { Congo, Liberia, Central African Republic, Mauritania, Eritrea, Namibia, Gam- } \\
\text { bia, Botswana, Gabon, Lesotho, Guinea-Bissau, Equatorial Guinea, Mauritius, } \\
\text { Eswatini, Djibouti, Comoros, Cabo Verde, Sao Tome and Principe, Seychelles }\end{array}$ \\
\hline
\end{tabular}

[30]. This search included articles published from January 2000 to May 2021 and yielded 6,396 results.

\section{Selection criteria}

Initially, all published literature related to the contamination of herbal medicine with drug-resistant bacteria in Africa was collected irrespective of the quality, research design used, and the attributes of the herbal samples studied, such as formulation, diseases treated, dosage, storage, precautions, and adverse effects. The final selection and inclusion of the publications were done using standardized protocols [31]. Studies that were included met the following conditions: they must have been fulltext articles published in the English language, in peerreviewed journals, between 2000 and 2021; and must have performed isolation, identification, and phenotypic and/or genotypic drug-resistance profiling of bacterial contaminants in commercial HM in African countries. The exclusion was based on: research conducted outside Africa, research investigating other microbial contaminants and adulterants, review articles, and research published after January 2000 and before May 2021.

\section{Review process}

\section{Data extraction from the journal articles}

Six reviewers (AW, HMK, SA, EK, AN, GA), extracted data independently from the 18 eligible articles. Each researcher individually entered the data in spreadsheets, capturing these attributes: first author, year of publication, country, formulation, disease (s) treated, sample size, sampling techniques, mode of administration, potentially pathogenic bacterial species isolated, number of samples contaminated with bacteria, number of samples contaminated with drug-resistant bacteria, drug resistance phenotypes reported, drug resistance genes detected, and resistance plasmids. The reviewers compared their records every week to remove any duplicates and reconcile their data through a consensus.

\section{Quality assessment}

Quality assessment for the eligible studies was independently performed by four reviewers (AW, SA, JES, and DA), and a quality score ranging from 0 to 10 was awarded to each study. Quality scoring was done based on three dimensions namely; sample collection, comparability, outcome, and statistical analysis, as described in guidelines of the Newcastle-Ottawa scale [31]. Studies with a score of 9-10 were described as very good, 7-8 as good study, 5-6 as satisfactory study, and less than 5 as unsatisfactory. Consistency in quality assessment of the articles was supervised by two co-authors not involved in the scoring, i.e. (EKK and JLN).

\section{Data analysis}

The number of eligible studies and combined frequencies of potentially pathogenic bacterial species, drug resistance phenotypes, and drug resistance genes reported in the research articles, and proportions of herbal medicine samples contaminated with drugresistant bacteria, were evaluated and presented using graphs and tables. A random-effects model was used to determine the pooled prevalence of drug-resistant bacteria, as well as their resistance traits, from the studies where heterogeneity was high; however, a fixed-effects model was used in cases where heterogeneity of the respective studies was low [32]. The results were presented using forest plots. Pooled prevalences were compared for association with different variables during the subgroup analysis and the P values at $95 \% \mathrm{CI}$ were determined. Cochran's $Q$ test and the $I^{2}$ statistic were evaluated to examine the heterogeneity of the eligible studies for our meta-analysis. Publication bias was examined by constructing funnel plots. Sources of heterogeneity of the eligible studies were assessed by conducting sensitivity analysis, subgroup analysis, and meta-regression. All the analyses were performed using 
statistical software called MedCalcs (https://www. medcalc.org/), and $P<0.05$ was considered significant in all cases. Five authors (AW, JES, DA, GA, AKT), were involved in the data analysis.

\section{Results}

\section{Screening for eligible studies}

A standard search strategy, i.e., the Preferred Reporting Items for Systematic Reviews and Meta-Analyses (PRISMA), was used to screen for eligibility of the published articles concerning drug-resistant bacterial contamination of herbal medicines in Africa between 2000 and 2021 [33]. Eighteen research articles with a total sample size of 1111 met our inclusion criteria (Fig. 1).

The recent studies that suited our inclusion criteria were found in Uganda, Ethiopia, Nigeria, Tanzania, Kenya, and South Africa (Fig. 2).
Characteristics of eligible studies on drug resistance traits of medically important bacteria isolated from commercial herbal medicines in Africa from 2000 to 2021

The characteristics of eligible studies are summarized in Table 2, Figs. 3 and 4. A total of 18 eligible studies, with a sample size of 1111 were included in this Meta-Analysis. Nigeria had the greatest number of eligible studies (11, $61 \%$ ), with a total sample size of 533, followed by Kenya and Ethiopia with $(2,11 \%)$ studies each and total sample sizes of 238, and 105 respectively. A study by Niyoshima, 2016 in Uganda, had the largest sample size of 170, while studies in Nigeria by; Osungunna et al. 2010, Omoruyi et al. 2017, and Braide et al. 2013 had the smallest sample size of 10 each. Most studies were published between the years 2011 and 2021 (14/18, 77.8\%), with a total sample size of $909(81.8 \%)$ compared to the studies published in $2000-2010(4 / 18 ; 22.2 \%)$, with a total sample size of 201 (18.2\%). All the eligible studies used conventional culture

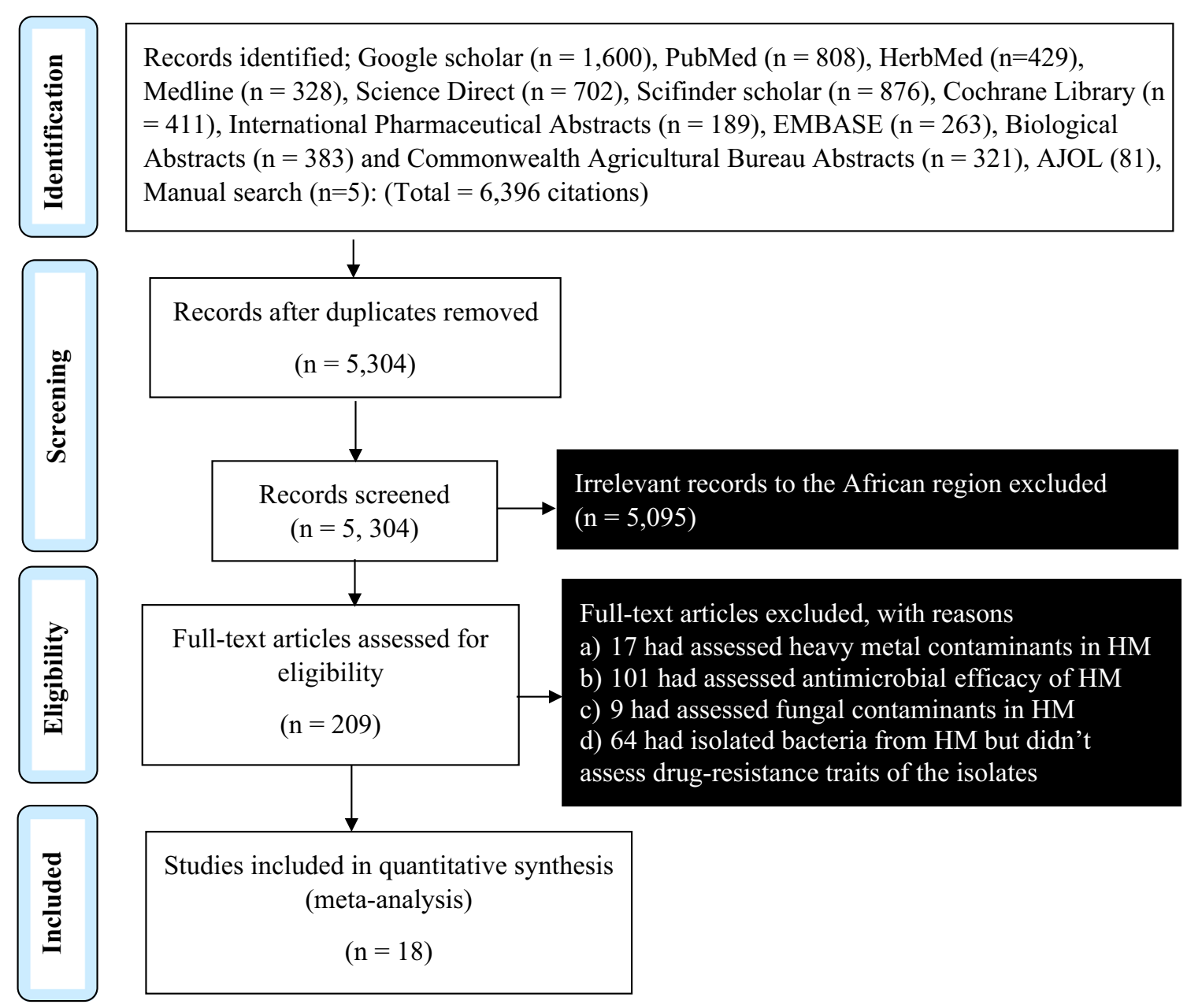

Fig. 1 Flow chart for study eligibility screening of the research articles related to drug-resistant bacterial contamination of commercial herbal medicine in Africa, following PRISMA criterion 


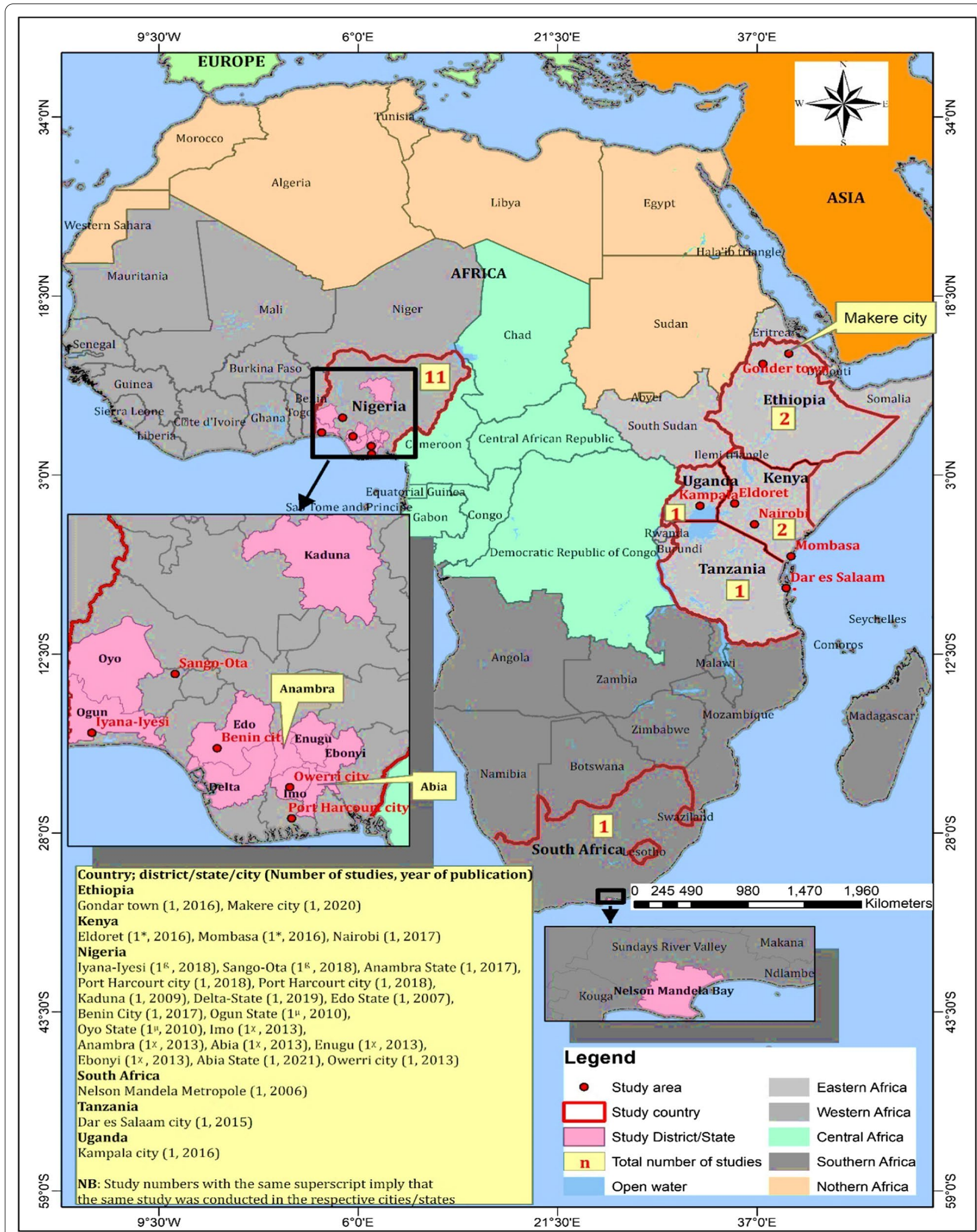

Fig. 2 Distribution of representative countries that published research articles on drug resistance traits of medically important bacteria isolated from commercial herbal medicine in Africa from 2000 to 2021 


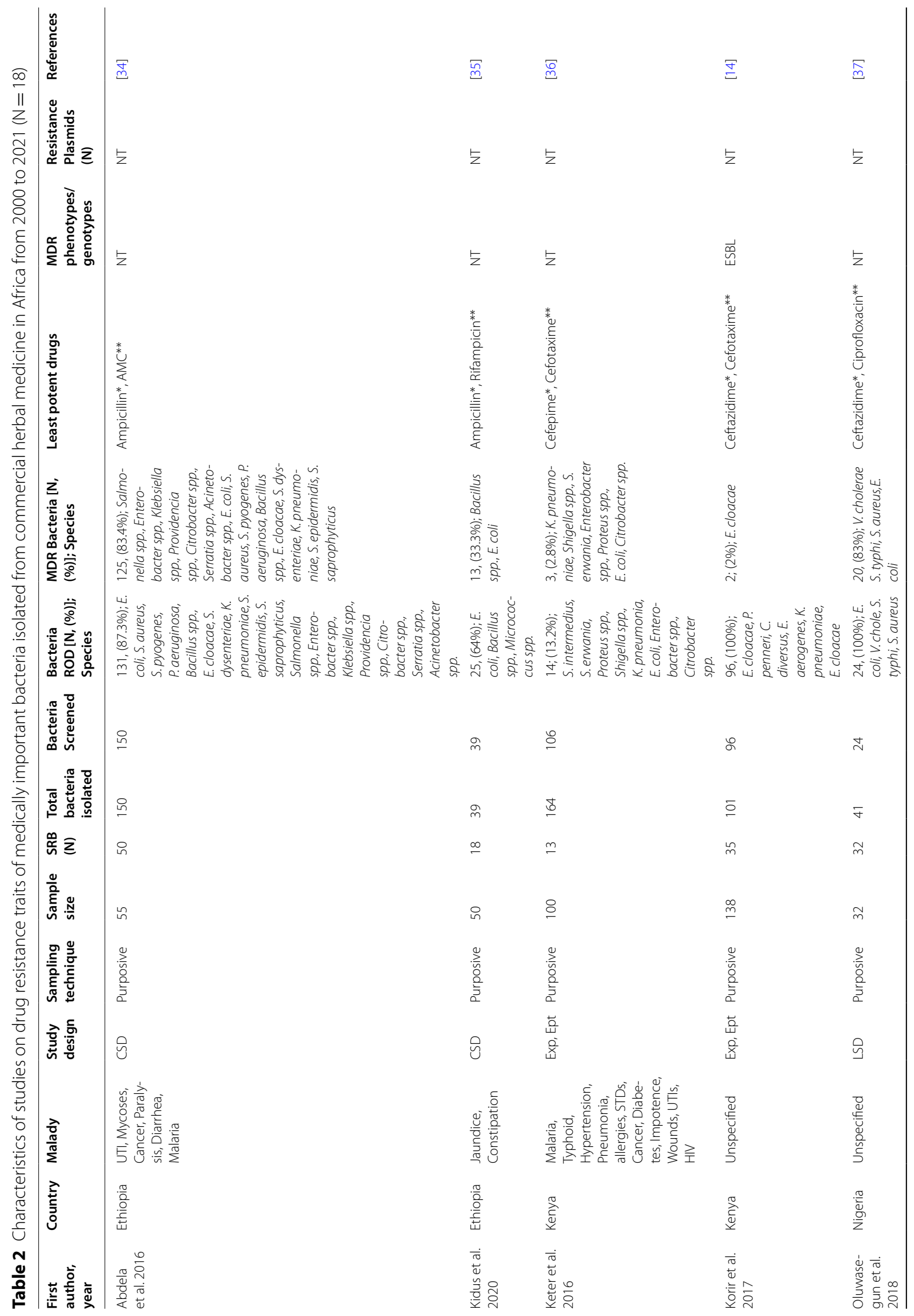




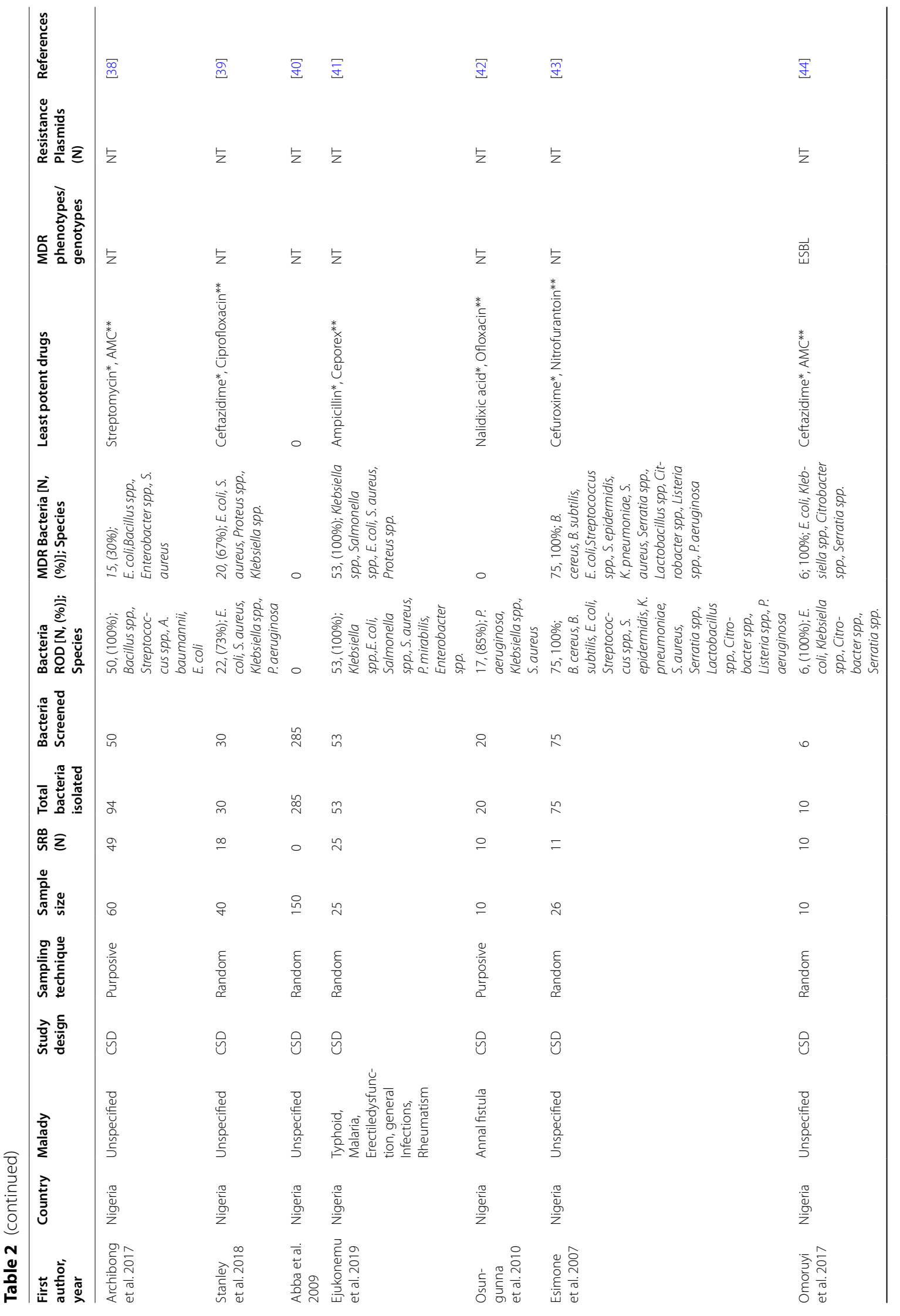




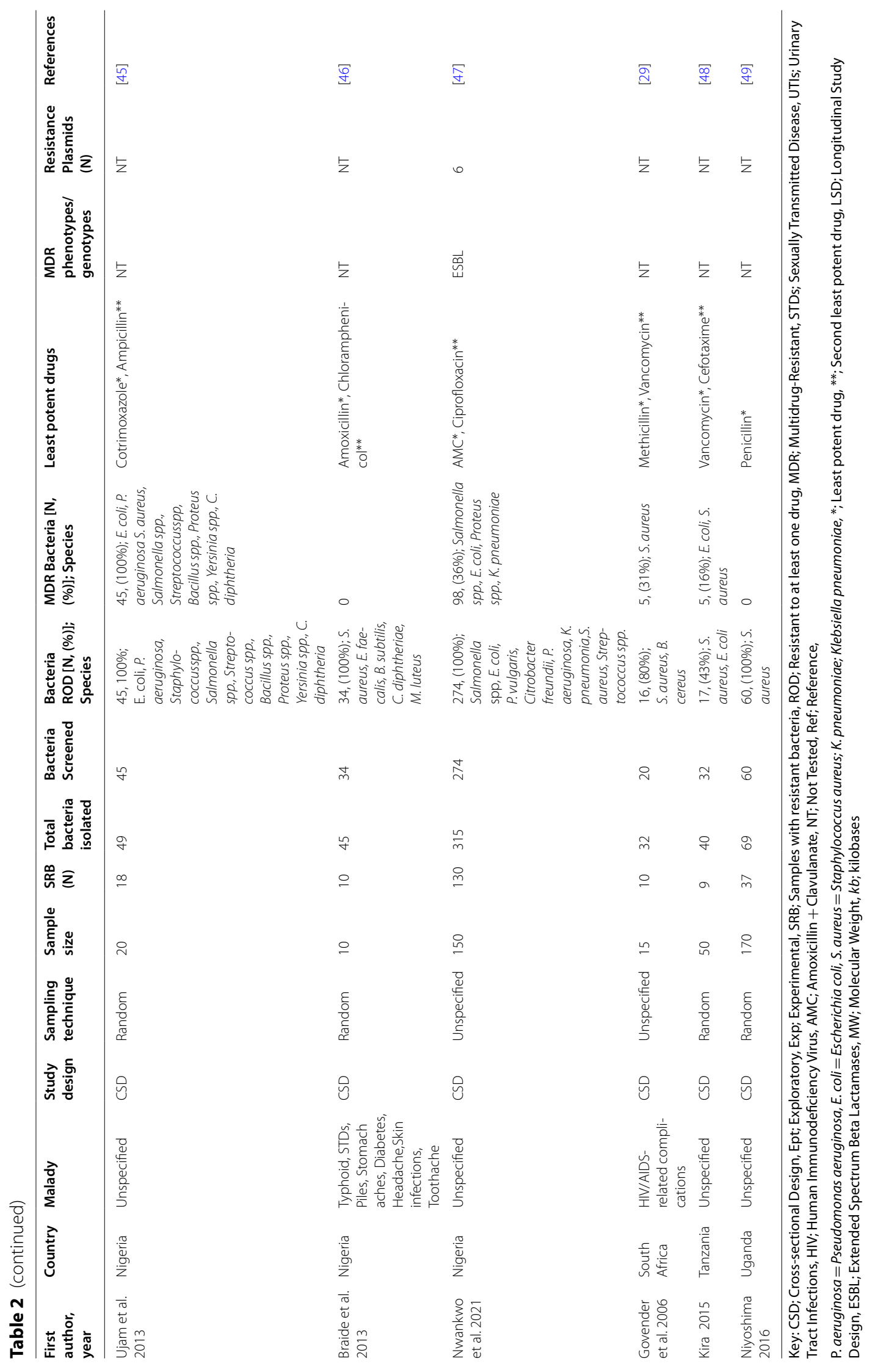




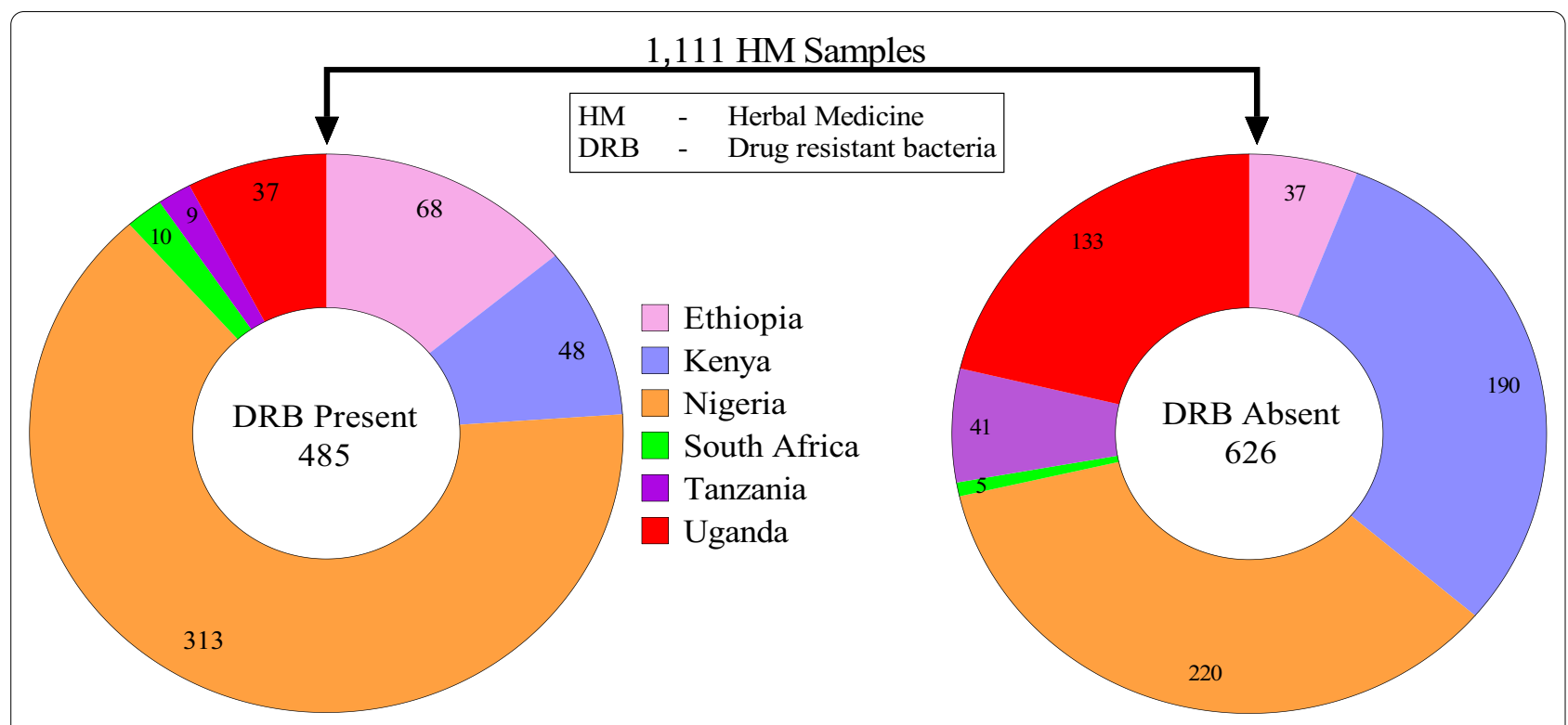

Fig. 3 Distribution of commercial herbal medicines laden with drug-resistant bacterial contaminants in Africa from 2000 to 2021

to isolate bacterial contaminants from HM and phenotypic methods (colony morphology, gram staining, and biochemicals), to characterize the isolates. These studies used Kirby-Bauer disk-diffusion methods to profile the drug resistance phenotypes of bacterial isolates, and one study (4.5\%) additionally applied Polymerase Chain Reaction (PCR) to examine the resistance genotypes [14].

The distribution of samples that were found to possess drug-resistant bacterial contaminants (Fig. 3).

Overall, 1612 bacterial strains of potential medical importance were isolated from 1111 herbal medicine samples. Of these, 1,399 isolates were screened for drug resistance traits. A total of 1210 (86.5\%), isolates exhibited resistance to at least one antibacterial drug. The prevalence of such bacteria among the countries where eligible studies existed varied widely. A study conducted by Abba et al. 2009 in Nigeria reported the least prevalence of bacteria that were resistant to at least one conventional drug: $0 \%(95 \% \mathrm{CI}=0.00-5.96 \%)$ [40]. In their study, all the 285 isolates were found to be sensitive to the drugs tested i.e., Amoxicillin, Erythromycin, Ampicillin, Ofloxacin, Cefaclor, Streptomycin, Chloramphenicol, and Tetracycline. The highest prevalence of bacteria that were resistant to at least one antibacterial agent was $100 \%$, and this was reported by $9(50 \%)$ of the eligible studies, found in Kenya and Nigeria [14, 37, 38, 41, 43-47], (Fig. 5a). The most potent antibiotic as reported by $6(33.30 \%)$ of the eligible studies was Gentamicin. Multidrug resistance (MDR) [Resistance of a strain to at least three drugs that belong to different drug classes] were reported in 504 $(36.0 \%)$ of the 1, 399 isolates screened. Nigeria reported the highest number of MDR pathogens (290/504, $57.80 \%)$, while Uganda reported the least (0/504, 0.00\%). Escherichia coli was the most frequently reported MDR species $(121 / 504,24.01 \%)$, followed by Staphylococcus aureus $(56 / 502,11.1 \%)$ as shown in Fig. 4.

\section{The pooled prevalence of bacterial contaminants that were resistant to at least one conventional drug in the African countries between 2000 and 2021}

The overall pooled prevalence of bacteria that were resistant to at least one drug, among the herbal medicines in Africa from 2000 to 2021 was 86.51\% (95\% $\mathrm{CI}=61.247-99.357 \%)$, with heterogeneity $\left(I^{2}\right)$ of $99.17 \%$ $(p<0.0001)$ (Fig. 5a). We constructed a funnel plot to gauge publication bias. Though the eligible studies were highly heterogeneous $(p<0.0001)$, the funnel plot exhibited symmetrical spread in terms of relative weight and effect size, therefore demonstrating no evidence of publication bias (Fig. 5b).

\section{Meta-analysis of sub-groups}

Since the eligible studies were highly heterogeneous, we clustered the analysis into seven categories. The clustering was based on (a): prevalence of multi-drug resistant bacteria per (i) country, (ii) year of publication, (iii) disease treated; (b) Least potent antibacterial drugs; (c) Least potent drug classes; (d) Drug resistance genes detected; and (e) Resistance plasmids detected (Table 2). Nations with only one eligible study, viz; Uganda, Tanzania, and South Africa were left out during meta-analysis of the sub-group "country of study". 


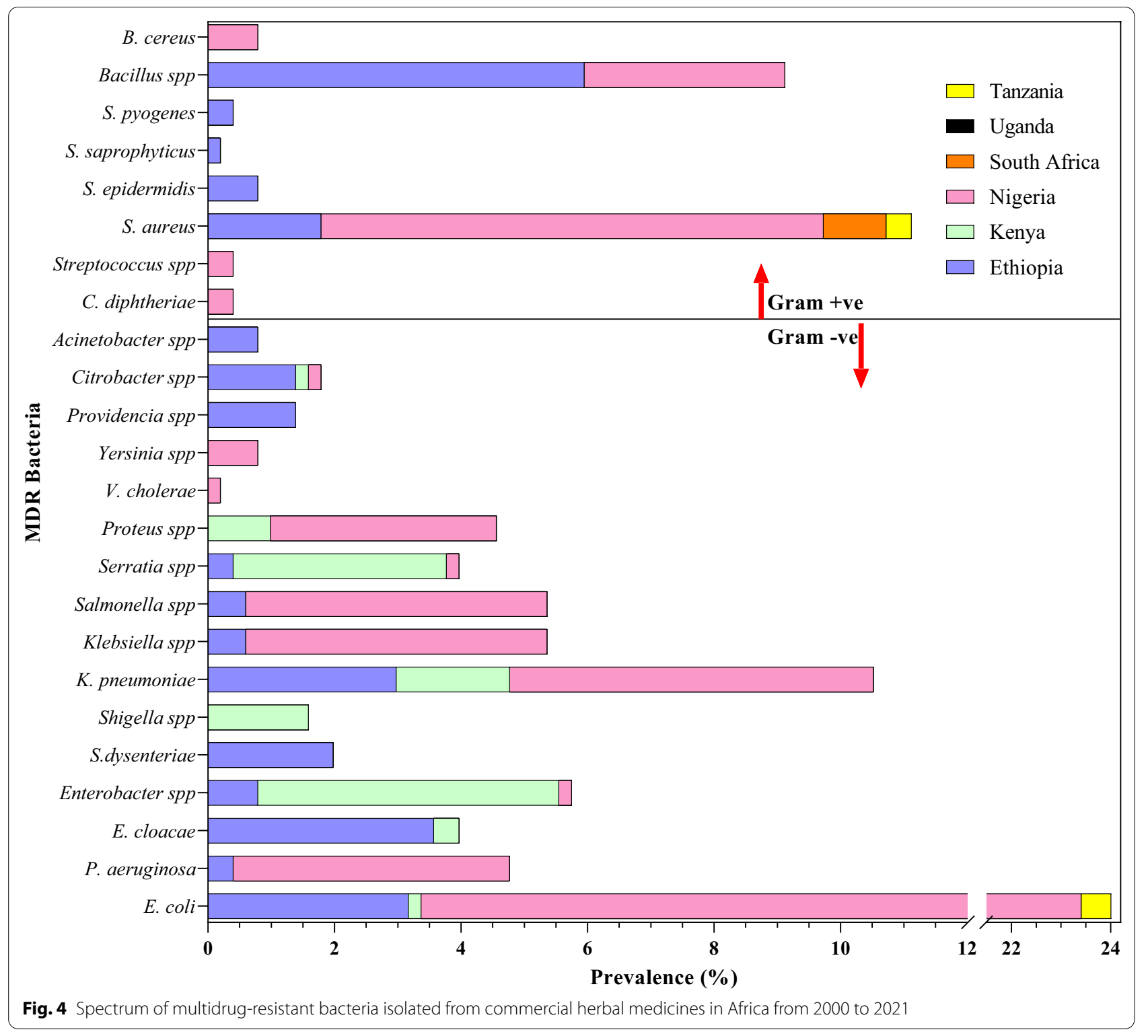

Similarly, diseases treated, and the least potent drugs, that were reported by a single study were not included during the meta-analysis of the respective sub-groups. Only one type of antibiotic resistance genes was reported, viz: Extended Spectrum $\beta$-Lactamases (ESBL) [14], and a single study in Nigeria, by Nwankwo et al. [47], reported the presence of resistance plasmids; thus the sub-groups, "drug resistance genes detected"; and "resistance plasmids detected" were considered unsuitable for meta-analysis.

In most of the categories considered for sub-group analysis, heterogeneity $\left(I^{2}\right)$ declined below the value $\left(I^{2}=97.6 \%, p \leq 0.0001\right)$ reported in the overall metaanalysis of bacterial resistance to at least one drug
(Fig. 5a); except for MDR prevalence in the years 2011 to $2021(98.16 \%, p \leq 0.0001)$, erectile dysfunction $\left(I^{2}\right.$ $=98.09 \% ; p \leq 0.0001)$, Typhoid $(98.83 \%, p \leq 0.0001)$, diabetes $(98.57 \%, p \leq 0.0001)$, and the herbal drugs for which the published studies $(\mathrm{n}=11)$, did not specify the type diseases that were claimed to treat $(97.67 \%$, $p \leq 0.0001$ ) (Table 2).

At the country level, the highest and lowest prevalence of multi-drug resistance phenotypes in bacterial contaminants of herbal medicines were reported in Ethiopia; 60.18\% (95\% CI $=13.15-97.27 \%)$, and Kenya; $25.53 \%$ ( $95 \% \mathrm{CI}=3.70$ to $90.23 \%$ ) respectively (Table 2). There was no evidence of publication bias in the countries (Ethiopia, Kenya, and Nigeria) that were 


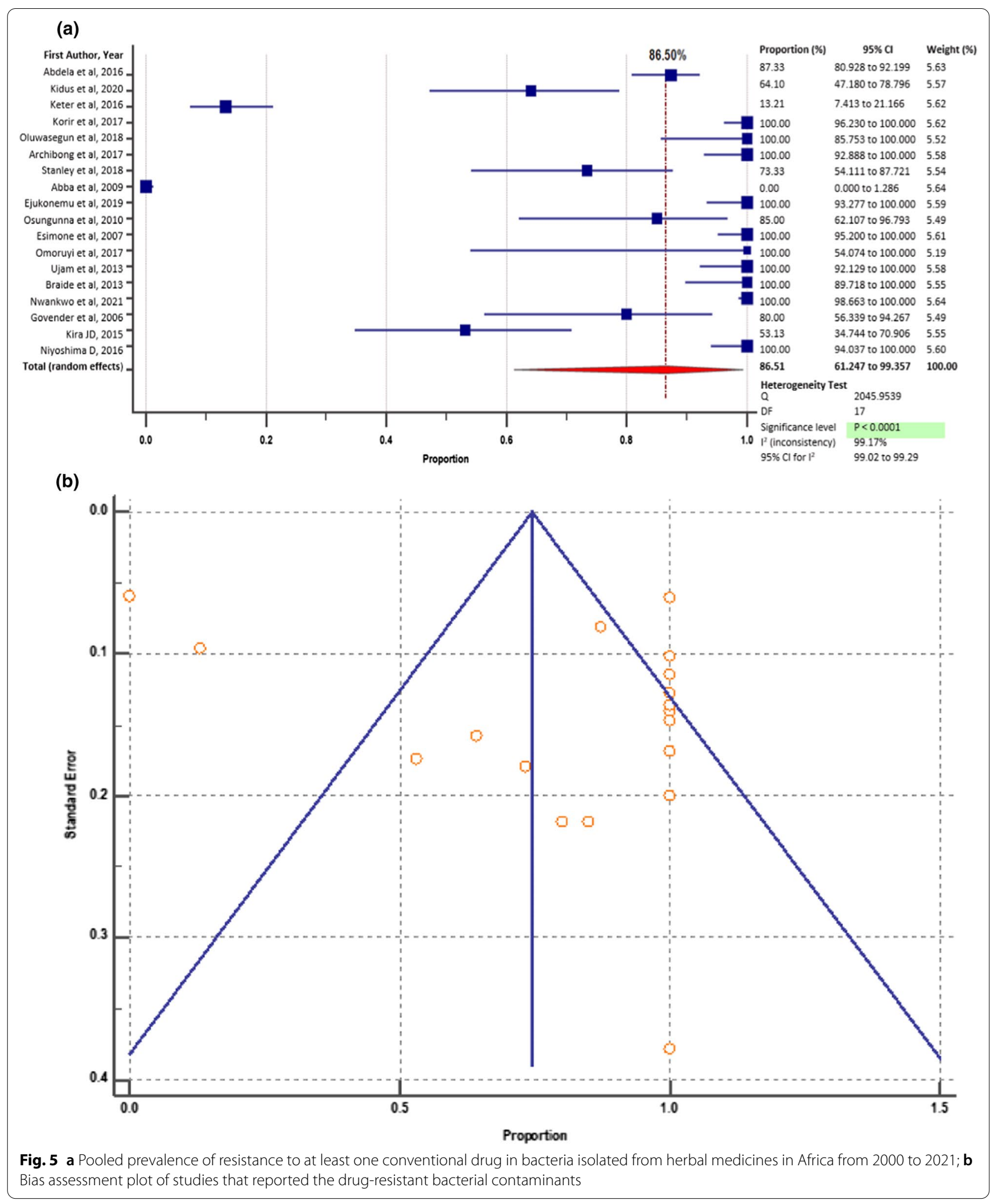


considered for this sub-group. The pooled prevalence of MDR bacteria in Ethiopia was significantly higher than in Kenya $(p<0.0001)$ and in Nigeria $(p=0.0364)$.

About the variation of multi-drug resistant bacterial strains per year of publication, the period between 2011 and $2021(\mathrm{~N}=14)$ registered the highest pooled prevalence of MDR bacteria, 50.02\% (95\% CI $=27.20$ $72.83 \%$ ), as compared to $11.80 \%$ (95\% CI $=7.85$ $41.54 \%)$ registered between 2000 to $2010(n=4)$. The prevalences were significantly different $(p<0.0001)$, in the two study periods (Table 2).

About the disease categories, the herbal drugs suggested for the management of erectile dysfunction harbored the highest pooled prevalence of MDR bacterial contaminants: $86.78 \%$ (95\% CI $=32.51-95.25 \%)$, and this was significantly different from the prevalence in the herbal drugs used to manage the rest of the diseases except malaria $(p=0.7301)$. The herbal drugs proposed for treating diabetes contained the lowest MDR prevalence; $22.54 \%$ ( 8.88 to $92.43 \%$ ).
Ceftazidime $(\mathrm{n}=3)$, was the least potent antibacterial drug. The pooled prevalence of resistance to Ceftazidime was $95.10 \%$ ( $95 \% \mathrm{CI}=78.51$ to $99.87 \%$ ), followed by Ampicillin at $81.15 \%(\mathrm{CI}=47.61$ to $99.21 \%)$. The pooled prevalence of resistance to these two drugs was significantly different $(p=0.0002)$. The least potent drug class was the 3rd generation Cephalosporins, with a pooled prevalence of $94.78 \%$ (73.65 to $99.39 \%$ ). The pooled prevalence of 3rd generation Cephalosporin resistance was not significantly different from that of other drug classes, viz; Penicillins $(p=0.0677)$ and all $\beta$-lactam drugs combined $(p=0.3123)$ (Tables 2,3$)$. The anti-bacterial drugs and drug classes that were reported as least potent in a single study, hence excluded from the meta-analysis are shown in Table 4. In these studies, resistance to Augmentin (Amoxicillin/clavulanic) manifested in the greatest number of isolates $(\mathrm{n}=154 ; 56.2 \%)$, and this was significantly different from resistance to other drugs except Cefepime $\left(\chi^{2}=0.937 ; p=0.3331\right)$, Methicillin $\left(\chi^{2}=3.360\right.$; $p=0.0668)$, and Vancomycin $\left(\chi^{2}=38.197 ; p=0.8076\right)$. Among the drug classes, there was high resistance to

Table 3 Sub-group analysis of the pooled prevalence of multidrug resistance, and the least potent drugs among bacterial contaminants of herbal medicines in Africa from 2000 to 2021

\begin{tabular}{|c|c|c|c|c|c|}
\hline \multirow[t]{2}{*}{ Variable } & \multicolumn{5}{|l|}{ Analysis } \\
\hline & $\begin{array}{l}\text { Number of } \\
\text { studies }\end{array}$ & Prevalence $\%(95 \% \mathrm{Cl})$ & $P$ value & $\mathrm{I}^{2}(\%)(95 \% \mathrm{Cl})$ & $P$ het \\
\hline \multicolumn{6}{|c|}{ MDR bacteria per country of study } \\
\hline Ethiopia & 2 & 60.18 (13.15 to 97.27) REF & & 97.16 (92.69 to 98.90$)$ & $<0.0001$ \\
\hline Kenya & 2 & 25.53 (3.70 to 90.23$)$ & $<0.0001$ & 99.10 (98.25 to 99.54$)$ & $<0.0001$ \\
\hline Nigeria & 11 & 49.35 (22.78 to 76.12$)$ & 0.0364 & 97.93 (97.24 to 98.44$)$ & $<0.0001$ \\
\hline \multicolumn{6}{|c|}{ MDR bacteria per year of publication } \\
\hline 2021 to 2011 & 14 & 50.02 (27.20 to 72.83$)$ REF & & 98.16 (97.66 to 98.55$)$ & $<0.0001$ \\
\hline 2010 to 2000 & 4 & $11.80(7.85$ to 41.54$)$ & $<0.0001$ & 95.08 (90.38 to 97.48$)$ & $<0.0001$ \\
\hline \multicolumn{6}{|c|}{ MDR bacteria per disease treated } \\
\hline Erectile dysfunction & 2 & 86.78 (32.51 to 95.25) REF & & 98.09 (95.58 to 99.18) & $<0.0001$ \\
\hline HIV/AIDS complications & 2 & $44.56(13.58$ to 78.15$)$ & $<0.0001$ & 89.11 (59.13 to 97.10$)$ & 0.0024 \\
\hline Urinary tract infections & 2 & 72.99 (49.51 to 91.11) & 0.0044 & 93.55 (49.51 to 91.11) & 0.0001 \\
\hline Malaria & 3 & 85.43 (59.59 to 99.11$)$ & 0.7301 & 96.23 (92.02 to 98.22 ) & $<0.0001$ \\
\hline Cancer & 2 & 72.99 (49.51 to 91.11) & 0.0044 & 93.55 (79.10 to 98.01$)$ & 0.0001 \\
\hline Typhoid & 3 & 54.50 (2.07 to 99.71$)$ & $<0.0001$ & 98.83 (98.03 to 99.31) & $<0.0001$ \\
\hline Diabetes & 2 & 22.54 (8.88 to 92.43 ) & $<0.0001$ & 98.57 (96.91 to 99.34) & $<0.0001$ \\
\hline Unspecified diseases & 11 & 39.19 (17.32 to 63.65) & $<0.0001$ & 97.67 (96.86 to 98.26 ) & $<0.0001$ \\
\hline \multicolumn{6}{|l|}{ Least potent drugs } \\
\hline Ceftazidime & 3 & 95.10 (78.51 to 99.87) REF & & 87.48 (70.14 to 94.75$)$ & $<0.0001$ \\
\hline Ampicillin & 3 & 81.15 (47.61 to 99.21$)$ & 0.0002 & 96.29 (92.17 to 98.24$)$ & $<0.0001$ \\
\hline \multicolumn{6}{|l|}{ Least potent drug classes } \\
\hline 3rd Generation cephalosporins & 4 & 94.78 (73.65 to 99.39) REF & & 91.64 (78.64 to 96.73$)$ & $<0.0001$ \\
\hline Penicillins & 6 & 89.57 (69.78 to 99.43) & 0.0677 & 95.35 (92.21 to 97.22) & $<0.0001$ \\
\hline All $\beta$-lactam drugs & 13 & 92.45 (81.59 to 98.73$)$ & 0.3123 & 95.99 (94.47 to 97.09 ) & $<0.0001$ \\
\hline
\end{tabular}

Bolded $P$-values are not significant

$\mathrm{MDR}=$ Multi-Drug Resistance, ESBL = Extended Spectrum $\beta$-Lactamase, $\mathrm{Cl}=$ Confidence Interval, het $=$ Heterogeneity, HIV $=$ Human Immunodeficiency Virus, AIDS $=$ acquired immunodeficiency syndrome, $R E F=$ Reference value 
Table 4 Antibacterial drugs and drug classes that were reported by single studies, to be the least potent among bacterial contaminants of herbal medicines in Africa, 2000-2021

\begin{tabular}{|c|c|c|c|c|c|}
\hline Drug & Number studies & Isolates screened ( $\mathrm{N}$ ) & $\begin{array}{l}\text { Resistant isolates } \mathrm{N} \\
\text { (\%) }\end{array}$ & $x^{2}$ & $P$-value \\
\hline Augmentin & 1 & 274 & $154(56.2)$ & & \\
\hline Cefepime & 1 & 106 & $67(63.2)$ & 0.937 & 0.3331 \\
\hline Streptomycin & 1 & 50 & $50(100.0)$ & 32.558 & $<0.0001$ \\
\hline Cefuroxime & 1 & 75 & $75(100.0)$ & 46.363 & $<0.0001$ \\
\hline Nalidixic acid & 1 & 20 & $17(85.0)$ & 5.221 & 0.0223 \\
\hline Co-trimoxazole & 1 & 45 & $45(100.0)$ & 29.667 & $<0.0001$ \\
\hline Amoxicillin & 1 & 34 & $34(100.0)$ & 23.101 & $<0.0001$ \\
\hline Methicillin & 1 & 20 & $16(80.0)$ & 3.360 & 0.0668 \\
\hline Vancomycin & 1 & 32 & $17(53.1)$ & 0.0593 & 0.8076 \\
\hline Penicillin & 1 & 60 & $60(100.0)$ & 38.197 & $<0.0001$ \\
\hline \multicolumn{6}{|l|}{ Drug class } \\
\hline Glycopeptides & 1 & 32 & $17(53.1)$ & & \\
\hline $2^{\text {nd }}$ generation Cephalosporins & 1 & 75 & $75(100.0)$ & 38.094 & $<0.0001$ \\
\hline $4^{\text {th }}$ generation Cephalosporins & 1 & 106 & $67(63.2)$ & 0.575 & 0.4481 \\
\hline Aminoglycosides & 1 & 50 & $50(100.0)$ & 26.220 & $<0.0001$ \\
\hline Quinolones & 1 & 20 & $17(85.0)$ & 3.928 & 0.0475 \\
\hline Sulfonamides & 1 & 45 & $45(100.0)$ & 23.829 & $<0.0001$ \\
\hline$\beta$-lactam + $\beta$-lactamase inhibitor & 1 & 274 & $274(100.0)$ & 131.672 & $<0.0001$ \\
\hline
\end{tabular}

Bolded $P$-values are not significant

$x^{2}=$ Chi-square

$\beta$-lactam $+\beta$-lactamase inhibitors $(n=274 ; 100.0 \%)$, and minimal resistance to Glycopeptide drugs $(n=17 ; 53.1 \%)$. The resistance to Glycopeptides was significantly lower than the rest of the drug-classes except $4^{\text {th }}$ generation Cephalosporins $\left(\chi^{2}=0.575 ; p=0.4481\right)$ and Quinolones $\left(\mathrm{x}^{2}=3.928 ; p=0.0475\right)$ (Table 3$)$.

\section{Drug resistance enzymes, genes, and plasmids}

Two studies (10\%), studies screened the bacterial contaminants for MDR enzymes phenotypically [14, 47], while one study screened for MDR genes [44]. The former aimed at the detection of Extended Spectrum Beta-lactamase (ESBL) enzymes, while the latter screened for some of the genes that encode ESBL. Among the isolates screened for MDR enzymes and/ or genes, 89 (37.2\%) were ESBL positive, and these included; Salmonella spp., Proteus vulgaris, Klebsiella pneumoniae, and E. coli among others (Table 5). About the resistance genes, $b l a_{C T X-M}$-ESBL and $b l a_{C M Y}$ ESBL were confirmed in bacteria such as K. pneumoniae, and E. cloacae among others, in Nigeria [44]. Consequently, Nwankwo et al. 2021 screened for the presence of drugresistance plasmids in 103 bacterial isolates in Nigeria; of these, $6(5.8 \%)$ isolates were found to possess the targeted plasmids that were linked to the observed drug resistance phenotypes [47]. P. vulgaris possessed the highest number of plasmids $(\mathrm{N}=5 ; 83.3 \%)$, with the largest possessing a molecular weight of $23,130 \mathrm{~Kb}$, as shown in Table 1.

\section{Meta-regression}

Meta-regression analysis was performed to examine the continuous variables of bacterial resistance to at least one contemporary drug, and year of publication, as well as the sample size $(p>0.05)$. The results showed that the years of publication of the eligible studies were not significantly associated with the prevalence of bacterial resistance to at least one drug $(p=0.115)$ (Fig. 6a); however, the sample size was significantly associated with the prevalence of bacterial contaminants that were resistant to at least one modern antibacterial agent $(p=0.042)$ (Fig. 6b).

\section{Sensitivity analysis}

Sensitivity analysis involved the removal of one study which had the largest sample size [49]. Results show that there was a slight decline in the pooled prevalence of drug-resistant bacteria from the original $87.7 \%$ 
Table 5 Drug-resistance genes and plasmids identified in bacteria isolated from commercial herbal medicines in Africa from 2000 to 2021

\begin{tabular}{|c|c|c|c|c|}
\hline \multirow[t]{2}{*}{ Isolates screened $(\mathrm{N})$} & \multirow{2}{*}{\multicolumn{2}{|c|}{ MDR Phenotypes/genotypes }} & \multicolumn{2}{|c|}{ Isolates with MDR phenotypes/genotypes } \\
\hline & & & $\mathrm{N},(\%)$ & Species \\
\hline \multicolumn{5}{|c|}{ (a) Multi-drug resistance phenotypes and/or genotypes } \\
\hline 06 & \multicolumn{2}{|c|}{ ESBL } & & K.pneumoniae \\
\hline 98 & \multicolumn{2}{|l|}{ ESBL } & & Salmonella spp. \\
\hline 13 & \multicolumn{2}{|l|}{ ESBL } & & E. coli \\
\hline 13 & \multicolumn{2}{|l|}{ ESBL } & & P. vulgaris \\
\hline 13 & \multicolumn{2}{|l|}{ ESBL } & & K.pneumoniae \\
\hline \multirow[t]{2}{*}{96} & \multicolumn{2}{|l|}{$b l a_{C T X-M}-E S B L$} & & $\begin{array}{l}\text { P. penneri, K. pneumoniae, C. diversus, E } \\
\text { cloacae, M. morganii }\end{array}$ \\
\hline & \multicolumn{2}{|l|}{$b l a_{C M Y}-E S B L$} & & E. cloacae, E. aerogenes, K. pneumoniae \\
\hline \multicolumn{3}{|l|}{$\Sigma=239$} & \multicolumn{2}{|c|}{$\Sigma=89(37.2 \%)$} \\
\hline \multirow[t]{2}{*}{ Isolates tested (N) } & \multicolumn{2}{|c|}{ Resistance plasmids detected } & \multicolumn{2}{|c|}{ Isolates with drug resistance plasmids } \\
\hline & Number & $\mathrm{MW}(K b)$ & $\mathrm{N},(\%)$ & Species \\
\hline \multicolumn{5}{|l|}{ (b) Resistance plasmids } \\
\hline 16 & 1 & 9416 & $1(6.3 \%)$ & Salmonella spp. \\
\hline \multirow[t]{4}{*}{11} & 2 & 23,130 & $2(18.2 \%)$ & P. vulgaris \\
\hline & 1 & 2322 & $1(9.1 \%)$ & \\
\hline & 1 & 9416 & $1(9.1 \%)$ & \\
\hline & 1 & 2322 & $1(9.1 \%)$ & \\
\hline 47 & 0 & Nil & $0(0.0 \%)$ & Escherichia coli \\
\hline 29 & 0 & Nil & $0(0.0 \%)$ & Klebsiella pneumoniae \\
\hline$\Sigma=103$ & $\Sigma=06$ & & $\Sigma=06(5$ & \\
\hline
\end{tabular}

$\mathrm{ESBL}=$ Extended Spectrum $\beta$-lactamase enzymes, $\mathrm{MW}=$ Molecular Weight, $K b=$ kilobases
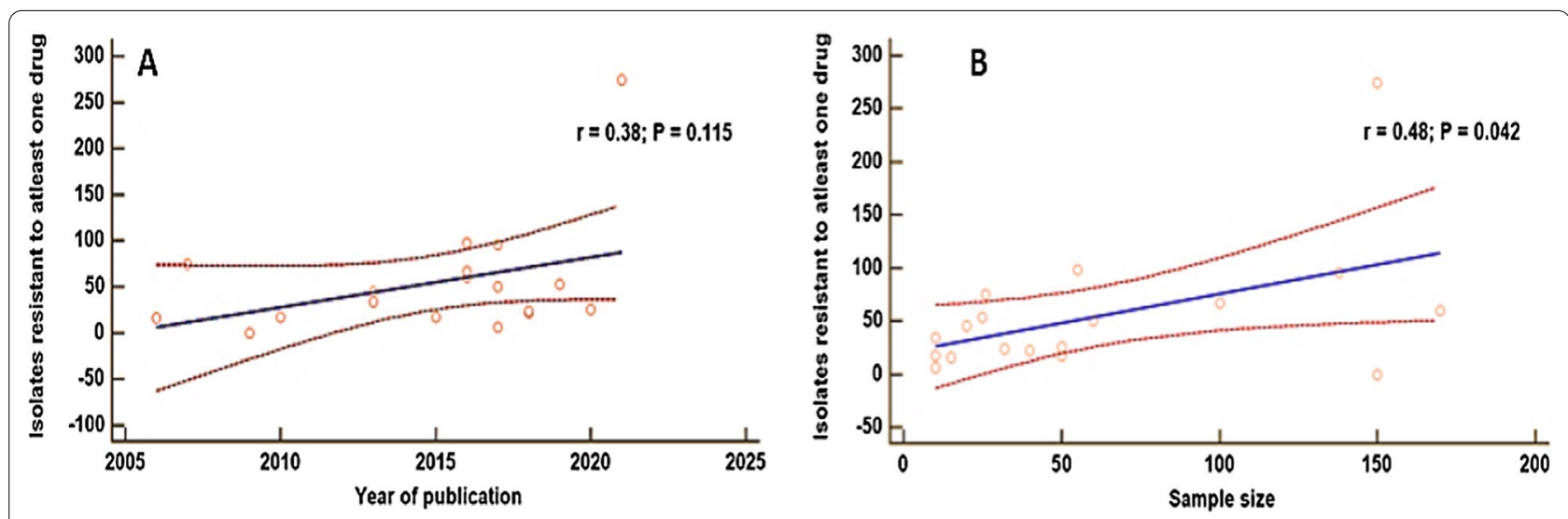

Fig. 6 Meta-regression analysis by the prevalence of bacterial resistance to at least one drug and year of publication (A), as well as the sample size (B), of the herbal medicines sold in Africa from 2000 to 2021

$(95 \% \mathrm{CI}=72.82-97.18 \%) \quad$ (Fig. $5 \mathrm{a})$, to $86.51 \% \quad(95 \%$ $\mathrm{CI}=70.401-96.898$ ) (Fig. 7), with heterogeneity $\left(I^{2}\right)$; $97.69 \%$ and $p<0.0001$.

\section{Discussion}

A total of eighteen original scientific studies that investigated the drug-resistance burden in bacteria recovered from commercial HM in Africa and published the findings online from 2000 to 2021 qualified for inclusion in 


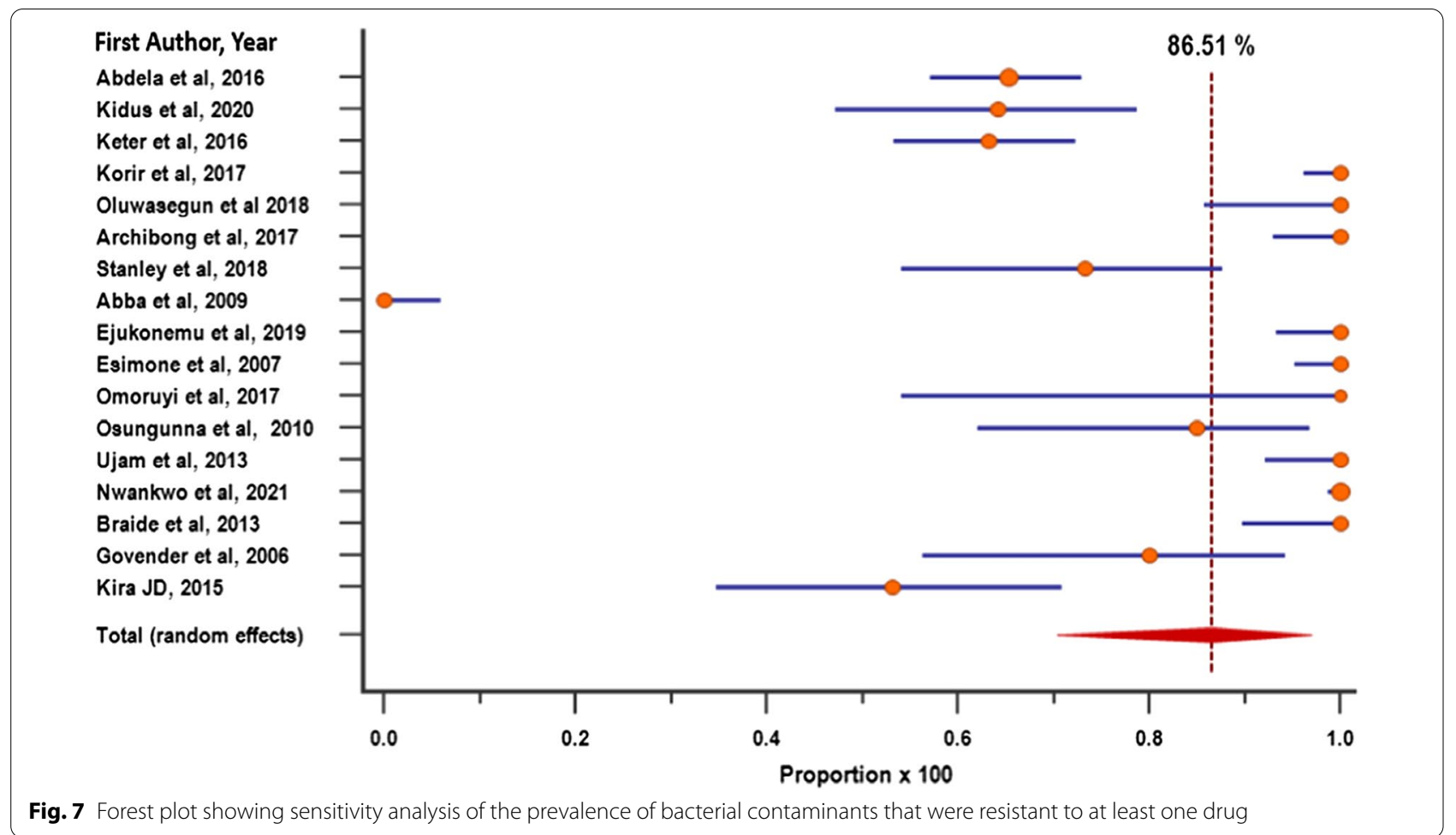

this meta-analysis. It would be interesting to compare these findings with the number of studies reported earlier in other continents, however, systematic reviews and/ or meta-analyses on this subject outside Africa remain scarce. In the current meta-analysis, the eighteen eligible studies were found in Uganda, Kenya, South Africa, Ethiopia, Tanzania, and Nigeria. Though some more studies related to bacterial contamination of herbal medicine were barely available in those six countries, plus a few other African states such as Malawi, Sudan, Cameroon, and Benin, the studies did not examine the drug-resistance traits of the isolated bacteria [23, 40, 50-61]. This highlights the need for more adequate research on this subject, in light of the escalating burden of antibacterial resistance in the African region [4-8]. The total sample size from the 18 studies was 1,111; from which 1,612 bacterial strains were isolated. Out of these bacteria, 1399 isolates were screened for drug sensitivity, and of these, 1210 exhibited resistance to at least one of the conventional antibacterial agents tested. Therefore, the pooled prevalence of resistance to at least one drug was $86.51 \%$ (95\% CI $=61.247-99.357 \%$ ); and the studies were highly heterogeneous $\left(I^{2}=99.17 \%\right.$; $\left.p<0.0001\right)$, with no demonstratable evidence of publication bias.

In 10 (55.6\%), of the eighteen eligible studies, the prevalence of resistance to at least one conventional drug was higher than the overall pooled prevalence (86.51\%), with the highest, (100\%), being reported by some studies in
Kenya, Nigeria and Uganda $(14,37,41,49)$. Overall, multidrug resistance (MDR) phenotypes were reported in 504 (36.0\%) of the 1399 isolates screened. Nigeria reported the highest prevalence of MDR pathogens, $57.80 \%$ $(\mathrm{n}=290)$, with Escherichia coli being the most prevalent, while Uganda reported the lowest, $0.00 \%(n=0)$. The low carriage of MDR in Uganda, as observed, remains elusive because only one eligible study was available for inclusion in this meta-analysis [49]. The eligible study aimed at isolating only one species (S. aureus), and the isolates were tested against a small number of antibiotics (Gentamicin, Chloramphenicol, Ampicillin, Penicillin, Tetracycline); besides the study did not attempt to examine the MDR traits [49].

The findings show that in the African region, Escherichia coli was the most frequently reported multidrugresistant bacterial contaminant of herbal medicine, with a pooled prevalence of $24.01 \%(n=121)$, followed by Staphylococcus aureus at $11.1 \%(\mathrm{n}=56)$; Others included; Salmonella spp., Bacillus spp., Shigella spp. and Klebsiella pneumoniae (Fig. 4). All these bacteria, except Bacillus spp., exist on the global list of resistant pathogens which the World Health Organization has identified, that need priority in research, discovery, and development of new antibiotics [62, 63]. The predominance of coliform bacteria such as E. coli is suggestive of the highly compromised hygiene associated with fecal contamination of plants, water, and other environmental resources [22]. Therefore, 
the presence of such microbes in the medicinal herbal end-products might partly be attributed to the potential inadequacy of quality control during harvesting, transporting, processing, and/or packaging; poor compliance to Good Manufacturing Practices (GMPs) and/or regulatory frameworks; illegal operation of the herbal medicine businesses leading to absolute lack of monitoring by the authorities. Further, the presence of drug-resistance traits in some bacteria, such as K. pneumoniae, and E. coli that are recovered from consumable products like herbal medicines, or humans and animals, has been reported to be indicative of the levels of antibiotic-resistant bacterial pollution in the environment $[64,65]$. Effective mitigation of the community spread of drug-resistant bacteria, therefore, requires a one health approach. One health is a collaborative, transdisciplinary scheme that promotes the achievement of optimal health outcomes given the interconnections among humans, plants, animals, and their shared environment [66].

Some of the highly prevalent MDR bacteria revealed by this meta-analysis are in alignment with the MDR strains isolated from commercial herbal medicines elsewhere. For example, in some parts of Asia, a high prevalence of MDR K. pneumoniae, S. aureus, and E. coli contaminants in herbal medicines have been reported [67]. Such species are commonly implicated in the community spread of multi-drug resistance in many parts of Europe and North America; with some studies reporting $K$. pneumoniae that has evolved resistance to all the currently known antibiotics $[68,69]$. This indicates that the species of bacteria that are disseminated by herbal medicines in Africa represent some of the world's most critical bacterial conduits of AMR beyond the African region.

Besides concerns related to AMR spread, the high prevalence of MDR coliforms such as E. coli in herbal medicine is indicative of the gross absence of hygiene, associated with fecal contamination of the herbal medicines. The contaminants may come from packaging gears, water, plant materials, and other environmental resources with which humans and/or animals interact closely [49]. Further, the abundant presence of primary pathogens such as Salmonella spp. and Shigella spp. in HM is of great clinical significance because they have been implicated in deadly outbreaks of diarrheal diseases such as typhoid fever in some parts of Africa [8, 70]. According to the World Health Organization, such microbes should have zero $(0 \%)$ presence in herbal medicine [71].

Overall, the least potent antibiotic drug was Ceftazidime; $95.10 \%$ (95\% CI=78.51-99.87\%), followed by Ampicillin; 81.15 (95\% CI $=47.61$ to $99.21 \%$ ), while the least resisted was Vancomycin $(53.1 \%, \mathrm{n}=17)$. Our metaanalysis revealed that the least potent conventional drugs by bacteria isolated from HM in Africa are somewhat different from those that are highly resisted by bacterial contaminants of herbal products elsewhere. For example, in North America, resistance by bacteria such as Bacillus spp., Erwinia spp., Staphylococcus spp., and E. cloacae isolated from commercial herbal products was reported in the order; Ampicillin, Nalidixic acid, Trimethoprim, Ceftriaxone, and Streptomycin [72]. As well, in Asia, the prevalence of resistance to various antibiotics by $S$. aureus herbal contaminants was in the order of; $93.33 \%, 90 \%, 86.66 \%, 70 \%, 63.33 \%$, and $53.33 \%$ for penicillin, tetracycline, gentamicin, erythromycin, trimethoprim-sulfamethoxazole, and ciprofloxacin respectively [73]. The high resistance to Ceftazidime [a $3^{\text {rd }}$ generation cephalosporin (3GC) drug], in HM contaminants as reported in this meta-analysis, is in tandem with the recent reports of the worldwide surging incidence of 3GC-resistant gram-negative bacteria, mostly belonging to family Enterobacteriaceae [74]. Cephalosporins, more so the 3rd and 4th generation cephalosporins are listed by the World Health Organization among the critically important antimicrobial drugs for humans and animals, due to their remarkable efficacy against diarrheal pathogens such as Salmonella spp., E. coli, and Campylobacter spp., among others $[75,76]$. The $3 G C s$ are relatively safe antibiotics, that are extraordinarily active against enteric gram-negative bacilli and other critical pathogens such as Haemophilus influenzae, Streptococcus agalactiae, Neisseria meningititidis, and Streptococcus pneumoniae among others [77-79]. Third-generation cephalosporins, therefore, serve as first-line drugs in the management of major diseases such as; pneumonia, meningitis, urinary tract infections, sepsis, gonorrhea, skin and soft tissue infections among others [80]. Of recent, there has been a rapid emergence of $3^{\text {rd }}$ generation cephalosporin-resistant bacteria worldwide, including in Africa [81-83]. This raises worries related not only to the treatment-cost burdens but also the clinical implications [77].

The pooled prevalence of Extended Spectrum $\beta$-lactamase (ESBL) genes was $37.2 \%$, and they were more predominant in some of the bacteria that possess potential significance in human medicine, such as; Salmonella spp. and Proteus penneri. In a study by Korir et al. 2017 in Kenya, specific ESBL types were examined; the $b l a_{C T X-M}$ and $b l a_{C M Y}$ genes were detected at a prevalence of $34.4 \%$ and $32.3 \%$ respectively [14]. These findings are in contrast with the resistance genes recently identified in bacteria such as $S$. aureus that contaminated HM in some parts of Asia. In the latter, mostly Fluoroquinolone resistance genes were detected viz; blaZ (63.33\%), tetK (60\%), ermA (46.66\%), msrA (43.33\%), aacA-D (43.33\%), and mecA (43.33\%), msrB (6.66\%), ermB (10\%), vanB (13.33\%), fexA (13.33\%), rpoB (20\%), and vatB (20\%) [73]. The occurrence 
of ESBL in the bacterial contaminants of HM in Africa is of great concern because infections caused by these bacteria are very common in most parts of this continent [22, 47, 74, 84-86]. The ESBL genes code for ESBL enzymes that confer resistance to almost all $\beta$-lactam antibiotics (such as penicillin derivatives, cephalosporins, and monobactams). Most of these antibiotics target broad spectra of bacterial pathogens [74]. In recent years, the treatment challenges attributed to ESBL have become a global public health threat, because the strains that produce these enzymes constitute some of the most common MDR groups of medically important bacteria around the world [74].

This meta-analysis revealed that $5.8 \%(\mathrm{n}=6)$ of the bacterial contaminants screened, harbored plasmids of varying molecular weights, and these were suggested to potentially underpin the resistance phenotypes observed in the isolates in which they were detected. The presence of plasmids in the bacteria isolated from HM raises worries because such mobile genetic elements permit the rapid spread of non-chromosomal drug-resistance traits from one bacteria to another through horizontal gene transmission [87]. Such scientific phenomena could partly explain why antibiotic-susceptible strains of some bacteria, for instance, $S$. aureus and E. coli were reported to develop resistance to conventional antibacterial drugs when subjected to commercial herbal drug concoctions in the United States of America [72, 88]. Therefore, the escalation of antibacterial drug resistance that is potentially mediated by consumption of unhygienic herbal products is not exclusive to the low developed African states alone. This meta-analysis was limited by; online availability and the low number of research articles published on drug-resistant bacterial contamination of HM in Africa, the small number of countries that contained eligible studies, and the language (only English studies were available online among the eligible studies). In addition, some of the studies aimed at isolating a few target pathogens, and the isolates were tested against a limited number of antibiotics. Moreover, some researchers screened gram-negative bacteria against penicillin, yet such organisms are inherently resistant to this drug given their cell wall composition and structure [89].

\section{Conclusions}

Herbal medicines in Africa possess highly drug-resistant bacterial contaminants. This points to a possible treatment failure when these contaminants are involved in diseases causation. More research on this subject should be done in the rest of the African countries, to fill the evidence gaps and support the formation of collaborative quality control mechanisms for the herbal medicine industry in Africa.

\section{Abbreviations}

AMR: Antimicrobial Resistance; ABR: Antibiotic Resistance; ESBL: Extended Spectrum $\beta$-lactamases; HM: Herbal Medicine; PRISMA: Preferred Reporting Items for Systematic Reviews and Meta-analyses.

\section{Acknowledgements \\ Not applicable.}

\section{Authors' contributions}

Abdul Walusansa (AW) and Savina Asiimwe (SA) conceived the research idea participated in designing the study, searching and reviewing the research articles, data analysis, and drafting of the manuscript. Hussein. M. Kafeero (HMK), Esther Katuura (EK), Alice Nabatanzi (AN), and Godwin Anywar (GA), participated in searching and reviewing the research articles, data analysis, and drafting of the manuscript. Arthur K. Tugume (AKT), Jamil. E. Ssenku (JES) and Dickson Aruhomukama (DA), participated in quality assessment, data analysis, and manuscript writing. Esezah. K. Kakudidi (EKK) and Jesca. L. Nakavuma (JLN) performed the overall supervision of this meta-analysis and manuscript writing. All authors read and approved the final manuscript.

\section{Funding}

Not applicable.

\section{Availability of data and materials}

Datasets generated and analyzed during this meta-analysis are available from the corresponding author on request.

\section{Declarations}

\section{Ethics approval and consent to participate}

Since our study units in this research were already published articles in the public domain, the study did not require any ethical approval and/or clearance.

\section{Consent for publication \\ Not applicable.}

\section{Competing interests}

The authors declare that they have no competing interests.

\section{Author details}

${ }^{1}$ Department of Plant Sciences, Microbiology and Biotechnology, School of Biosciences, Makerere University, Kampala, Uganda. ${ }^{2}$ Department of Medical Microbiology, Faculty of Health Sciences, Islamic University in Uganda, P. O. Box 2555, Kampala, Uganda. ${ }^{3}$ College of Veterinary Medicine, Animal Resources and Biosecurity, Makerere University, P. O. Box 7062, Kampala, Uganda. ${ }^{4}$ Department of Medical Microbiology and Immunology, Faculty of Health Sciences, Busitema University, Mbale, Uganda. ${ }^{5}$ Department of Immunology and Molecular Biology, Faculty of Health Sciences, Makerere University, Kampala, Uganda.

Received: 7 July 2021 Accepted: 5 January 2022

Published online: 21 January 2022

\section{References}

1. World Health Organization (WHO). Antimicrobial resistance: global report on surveillance. World Health Organization; 2014. Available from: https:// apps.who.int/iris/bitstream/handle/10665/112647/WHO_HSE_PED_AIP_? sequence $=1$

2. Gulen TA, Guner R, Celikbilek N, Keske S, Tasyaran M. Clinical importance and cost of bacteremia caused by nosocomial multidrug-resistant Acinetobacter baumannii. Int J Infect Dis. 2015;38:32-5. 
3. World Health Organization (WHO). Worldwide country situation analysis: response to antimicrobial resistance. 2015. Available from: https:/apps. who.int/iris/bitstream/10665/163468/1/9789241564946_eng.pdf

4. Jasovský D, Littmann J, Zorzet A, Cars O. Antimicrobial resistancea threat to the world's sustainable development. Ups J Med Sci. 2016;121(3):159-64. https://doi.org/10.1080/03009734.2016.1195900.

5. Mpaire Y, Wamala S, Uganda National Academy of Sciences (UNAS). Antibiotic Resistance in Uganda: Situation Analysis and Recommendations. Uganda Natl Acad Sci Kampala, Uganda. 2015; Available from: https:// www.cddep.org/wp-content/uploads/2017/06/uganda_antibiotic_resis tance_situation_reportgarp_uganda_0-1.pdf

6. Najjuka CF, Kateete DP, Kajumbula HM, Joloba ML, Essack SY. Antimicrobial susceptibility profiles of Escherichia coli and Klebsiella pneumoniae isolated from outpatients in urban and rural districts of Uganda. BMC Res Notes. 2016;9(1):235. https://doi.org/10.1186/s13104-016-2049-8.

7. Walusansa A, Iramiot JS, Najjuka CF, Aruhomukama D, Mukasa HK Kajumbula H, et al. High Prevalence of Antibiotic-Resistant Escherichia coli Serotype O157: H7 among Pastoral Communities in Rural Uganda. Microbiol Res J Int. 2020;36-43.

8. Walters MS, Routh J, Mikoleit M, Kadivane S, Ouma C, Mubiru D, et al. Shifts in geographic distribution and antimicrobial resistance during a prolonged typhoid fever outbreak — bundibugyo and Kasese Districts, Uganda, 2009-2011. Ryan ET, editor. PLoS Negl Trop Dis. 2014 Mar 6 [cited 2019 Sep 2];8(3):e2726. doi:https://doi.org/10.1371/journal.pntd. 0002726

9. Lowings M, Ehlers MM, Dreyer AW, Kock MM. High prevalence of oxacillinases in clinical multidrug-resistant Acinetobacter baumannii isolates from the Tshwane region, South Africa-an update. BMC Infect Dis. 2015;15(1):1-10. https://doi.org/10.1186/s12879-015-1246-8.

10. Ahmed AM, Shimamoto T, Shimamoto T. Characterization of integrons and resistance genes in multidrug-resistant Salmonella enterica isolated from meat and dairy products in Egypt. Int J Food Microbiol. 2014;189:39-44.

11. Onanuga A, Temedie TC. Multidrug-resistant intestinal Staphylococcus aureus among self-medicated healthy adults in Amassoma, South-South, Nigeria. J Health Popul Nutr. 2011;29(5):446.

12. De Boeck H, Vandendriessche $\mathrm{S}$, Hallin M, Batoko B, Alworonga J-P, Mapendo B, et al. Staphylococcus aureus nasal carriage among healthcare workers in Kisangani, the Democratic Republic of the Congo. Eur J Clin Microbiol Infect Dis. 2015;34(8):1567-72. https://doi.org/10.1007/ s10096-015-2387-9.

13. The Open University. Hygiene and Environmental Health Module: 8. Food Contamination and Spoilage: View as a single page. The open University, Ethiopia; 2018 [cited 2019 Aug 27]. Available from: https://www.open. edu/openlearncreate/mod/oucontent/view.php?id=194\&printable $=1$

14. Korir R, Anzala O, Jaoko W, Bii C, Ketera L. Multidrug-Resistant Bacterial Isolates Recovered from Herbal Medicinal Products Sold in Nairobi, Kenya. Heal Res J. 2017;40.

15. Pan X, Zhang A, Henderson GE, Rennie S, Liu C, Cai W, et al. Traditional, complementary, and alternative medical cures for HIV: rationale and implications for HIV cure research. Glob Public Health. 2019;14(1):152-60. https://doi.org/10.1080/17441692.2017.1413122.

16. Hexa Research. Herbal Medicine Market Size and Forecast, By Product (Tablets \& Capsules, Powders, Extracts), By Indication (Digestive Disorders, Respiratory Disorders, Blood Disorders), And Trend Analysis, 2014 - 2024. 2017. Available from: https://www.hexaresearch.com/research-report/ global-herbal-medicine-market

17. Kaadaaga HF, Ajeani J, Ononge S, Alele PE, Nakasujja N, Manabe YC, et al. Prevalence and factors associated with the use of herbal medicine among women attending an infertility clinic in Uganda. BMC Complement Altern Med. 2014;14(1):27. https://doi.org/10.1186/ 1472-6882-14-27.

18. Lubinga SJ, Kintu A, Atuhaire J, Asiimwe S. Concomitant herbal medicine and Antiretroviral Therapy (ART) use among HIV patients in Western Uganda: a cross-sectional analysis of magnitude and patterns of use, associated factors and impact on ART adherence. AIDS Care. 2012;24(11):1375-83. https://doi.org/10.1080/09540121.2011.648600.

19. Stanifer JW, Lunyera J, Boyd D, Karia F, Maro V, Omolo J, et al. Traditional medicine practices among community members with chronic kidney disease in northern Tanzania: an ethnomedical survey. BMC Nephrol. 2015;16(1):170. https://doi.org/10.1186/s12882-015-0161-y.
20. Okot DF, Anywar G, Namukobe J, Byamukama R. Medicinal plants species used by herbalists in the treatment of snakebite envenomation in Uganda. Trop Med Health. 2020;48:1-14. https://doi.org/10.1186/s41182020-00229-4.pdf.

21. Ochwang'i DO, Kimwele CN, Oduma JA, Gathumbi PK, Mbaria JM, Kiama SG. Medicinal plants used in treatment and management of cancer in Kakamega County, Kenya. J Ethnopharmacol. 2014;151(3):1040-55.

22. Walusansa A, Asiimwe S, Kafeero HM, Stanley IJ, Ssenku JE, Nakavuma $J \mathrm{~L}$, et al. Prevalence and dynamics of clinically significant bacterial contaminants in herbal medicines sold in East Africa from 2000 to 2020: a systematic review and meta-analysis. Trop Med Health. 2021;49(1):1-14. https://doi.org/10.1186/s41182-020-00295-8.

23. Kaume L, Foote JC, Gbur EE. Microbial contamination of herbs marketed to HIV-infected people in Nairobi (Kenya). S Afr J Sci. 2012;108(9-10):1-4. https://doi.org/10.10520/EJC125497.

24. Posadzki P, Watson L, Ernst E. Contamination and adulteration of herbal medicinal products (HMPs): an overview of systematic reviews. Eur J Clin Pharmacol. 2013;69(3):295-307. https://doi.org/10.1007/ s00228-012-1353-Z.

25. Basch E, Ulbricht C, Harrison M, Sollars D, Smith M, Dennehy C, et al. Alfalfa (Medicago sativa L.) A clinical decision support tool. J Herb Pharmacother. 2003;3(2):69-90.

26. Chan K. Some aspects of toxic contaminants in herbal medicines. Chemosphere. 2003;52(9):1361-71.

27. Job KM, Kiang TKL, Constance JE, Sherwin CMT, Enioutina EY. Herbal medicines: challenges in the modern world. Part 4. Canada and United States. Expert Rev Clin Pharmacol. 2016;9(12):1597-609.

28. Ulbricht C, Conquer J, Costa D, Hollands W, lannuzzi C, Isaac R, et al. An evidence-based systematic review of saffron (Crocus sativus) by the Natural Standard Research Collaboration. J Diet Suppl. 2011;8(1):58-114.

29. Govender S, Du Plessis-Stoman D, Downing TG, Van de Venter M. Traditional herbal medicines: microbial contamination, consumer safety and the need for standards. S Afr J Sci. 2006;102(5-6):253-5. https://doi.org/ 10.1186/s12906-019-2723-1.

30. United Nations (UN). Country classification. 2014. p. 146-7. Available from: https://www.un.org/en/development/desa/policy/wesp/wesp_ current/2014wesp_country_classification.pdf

31. Stang A. Critical evaluation of the Newcastle-Ottawa scale for the assessment of the quality of nonrandomized studies in meta-analyses. Eur J Epidemiol. 2010;25(9):603-5. https://doi.org/10.1007/s10654-010-9491-z.

32. Neyeloff JL, Fuchs SC, Moreira LB. Meta-analyses and Forest plots using a Microsoft Excel spreadsheet: step-by-step guide focusing on descriptive data analysis. BMC Res Notes. 2012;5(1):1-6. https://doi.org/10.1186/ 1756-0500-5-52.

33. Kafeero HM, Ndagire D, Ocama P, Walusansa A, Sendagire H. Sero-prevalence of human immunodeficiency virus-hepatitis B virus (HIV-HBV) co-infection among pregnant women attending antenatal care (ANC) in sub-Saharan Africa (SSA) and the associated risk factors: a systematic review and meta-analysis. Virol J. 2020;17(1):1-19.

34. Yesuf A, Wondimeneh Y, Gebrecherkos T, Moges F. Occurrence of Potential Bacterial Pathogens and Their Antimicrobial Susceptibility Patterns Isolated from Herbal Medicinal Products Sold in Different Markets of Gondar Town, Northwest Ethiopia. Int J Bacteriol. 2016;2016. Available from: https://pubmed.ncbi.nlm.nih.gov/27299154/

35. Kidus Tsehaye, Zenebe T. Isolation, Characterization and Identification of Contaminant Bacteria from Saccharum officinarum L. in vitro Culture in Tigray Biotechnology Center, Mekelle, Ethiopia. J Bacteriol Parasitol. 2020. doi: https://doi.org/10.35248/2155-9597.20.11.372.

36. Keter L, Too R, Mwikwabe N, Ndwigah S, Orwa J, Mwamburi E, et al. Bacteria contaminants and their antibiotic sensitivity from selected herbal medicinal products from Eldoret and Mombasa, Kenya. Am J Microbiol. 2016;7(1):18-28. https://doi.org/10.3844/ajmsp.2016.18.28.

37. Oluwasegun AF, Nejo VM. Microbial assessment of herbal products in Ota and its environs. Niger J Microbiol. 2017;31 (2):3479-84.

38. Archibong EJ, Igboeli CN, Okoro NC, Obika I. Microbiological assessment of some liquid herbal medications sold in Awka metropolis. Anambra State Bioeng Biosci. 2017;5(3):37-46.

39. Stanley CN, Ibezim C, Diorgu FC. Evaluation of the claims of microbiological activity and microbiological quality of some oral herbal medicinal products sold in Port-Harcourt metropolis. Microbiol Res J Int. 2018;1-16. 
40. Abba D, Inabo H, Yakubu S, Olonitola O. Contamination of herbal medicinal products marketed in Kaduna metropolis with selected pathogenic bacteria. African J Tradit Complement Altern Med. 2009;6(1). doi:https:// doi.org/10.4314/ajtcam.v6i1.57076

41. Ejukonemu FE, Isaac IO. Physicochemical and microbiological evaluation of Agbo (herbal decoction) sold in some parts of Warri metropolis, DeltaState, Nigeria. Infection. 4:0-7.

42. Osungunna MO, Oluremi BB, Talabi I. Comparative microbial quality of Jedi drinks sold in two major cities in Nigeria, Pakistan. J Nutr. 2010;9(8):769-72.

43. Esimone CO, Oleghe PO, Ibezim EC, Okeh CO, Iroha IR. Susceptibilityresistance profile of micro-organisms isolated from herbal medicine products sold in Nigeria. African J Biotechnol. 2007;6(24). Available from: file:///C:/Users/ABDUL/Downloads/58199-Article\%20Text-103011-1-1020100820.pdf

44. Omoruyi IM, Ogunsakin AO. Extended-spectrum beta-lactamase-producing Enterobacteriaceae (ESBL) isolated from herbal preparations. 2017. doi:https://doi.org/10.14419/ijh.v5i1.7317

45. Ujam NT, Oli AN, Ikegbunam MN, Adikwu MU, Esimone CO. Antimicrobial resistance evaluation of organisms isolated from liquid herbal products manufactured and marketed in South-Eastern Nigeria. J Pharm Res Int. 2013;548-62. Available from: https://www.journaljpri.com/index.php/ JPRI/article/view/17830

46. Braide W, Oranusi SU, Nwaoguikpe RN, Offor-Emenike IU, Nwosu IL, Akobondu C, et al. Evaluation of the microbiological status and antibacterial susceptibility pattern of some herbal remedies administered orally in Nigeria. Res J Eng Appl Sci. 2013;2(1):35-42. Available from: http://eprints. covenantuniversity.edu.ng/4050/1/Oranusi_et_al_(44)\%5B1\%5D.pdf

47. Nwankwo EO, Pipi OG, Onusiriuka KN. Antibiotic resistance and plasmid profile of bacteria pathogens found in liquid herbal preparations sold in Umuahia, Abia State, Nigeria.

48. Kira JD. Prevalence and antimicrobial susceptibility of bacteria isolated from herbal medicines vended in Morogoro municipality, Tanzania. Sokoine University of Agriculture; 2015. Available from: http://www.scielo. org.co/pdf/rcien/v21n2/0121-1935-rcien-21-02-00085.pdf

49. Niyonshima Derick. "Staphylococcus aureus" contamination levels in selected local herbal medicines sold in Kampala, Uganda. GRIN Verlag; 2016. Available from: https://www.amazon.com/Staphylococcus-Conta mination-Selected-Medicines-Kampala/dp/3668719152

50. Famewo EB, Clarke AM, Afolayan AJ. Identification of bacterial contaminants in polyherbal medicines used for the treatment of tuberculosis in Amatole District of the Eastern Cape Province, South Africa, using rapid 16S rRNA technique. J Heal Popul Nutr. 2016;35(1):1-9. https://doi.org/10. 1186/s41043-016-0064-y.

51. Kalumbi M. Bacterial and heavy metal contamination in selected commonly sold herbal medicine in Blantyre, Malawi. Malawi Med J. 2020;32(3):153-9. https://doi.org/10.4314/mmj.v32i3.9.

52. Ngemenya MN, Djeukem GGR, Nyongbela KD, Bate PNN, Babiaka SB, Monya E, et al. Microbial, phytochemical, toxicity analyses and antibacterial activity against multidrug-resistant bacteria of some traditional remedies sold in Buea Southwest Cameroon. BMC Complement Altern Med. 2019;19(1):1-11. https://doi.org/10.1186/s12906-019-2563-z.

53. Toukourou F, Baba-Moussa L. Quality-based microbial contamination analysis of nutraceuticals. Int Res J Biol Sci. 2013; Available from: https:// scholar.google.com/scholar?hl=en\&as_sdt=0\%2C5\&q=Quality-Based + Microbial+Contamination+Analysis+of+Nutraceuticals\&btnG=

54. Mohamed A, Aldaw E karar M, Mohamed A. Assessment of bacterial contamination of some medicinal plants available in Sudanese local market. Int J Innov Pharm Sci Res [In. 2016; Available from: www.ijipsr.com

55. Ihsan Mosa Ewad EL-Kareem, Hatil Hashim EL-Kamali ASE. Bacterial contamination of some medicinal plant materials sold at Omdurman local market, Khartoum state, Central Sudan. Int J Microbiol Mycol | IJMM I. 2017;6, No. 3, Available from: https://www.researchgate.net/publication/ 325396608

56. Pierre René Fotsing Kwetché, Ernest Djoko, Lenya Queen Beloe Mende S, Gamwo Dongmo, Josué Simo Louokdom, Anselme Michel Yawat Djogang, William lelorel Nankam Nguekap, Serge Honoré Tchoukoua JN. Microbiological quality of some herbal drugs in the southwest regional capital of Cameroon. Int J Recent Sci Res. 2018; Available from: http:// www.recentscientific.com
57. Temu-Justin M, Lyamuya E, Makwaya C, Antony PR, Mloka D. Microbiological quality assessment of natural therapeutic herbal drug products prepared locally in Dar es Salaam, Tanzania. Afr J Health Sci. 1998;5(34):140-3. https://doi.org/10.3329/bjb.v48i2.47675.

58. Idu M, Jimoh A, Ovuakporie-Uvo O. Microbial load of some polyherbal products from Lagos State, Nigeria. Int J Ethnobiol Ethnomed. 2015;1(1):1-14. Available from: http://citeseerx.ist.psu.edu/viewdoc/ download?doi=10.1.1.1043.1464\&rep=rep1\&type $=$ pdf

59. Ideh JE, Ogunkunle ATJ. User frequency and microbial contaminants of traditional oral powdered herbal formulations in Ogbomoso, Nigeria. J Med Plants Econ Dev. 2019;3(1):1-9. https://doi.org/10.4102/jomped.v3i1. 67.

60. MacDonald I, Omonigho S, Erhabor J, Efijuemue H. Microbial load of some medicinal plants sold in some local markets in Abeokuta, Nigeria. Trop J Pharm Res. 2010;9(3). doi:https://doi.org/10.4314/tjpr.v9i3.56285

61. Van Vuuren S, Williams VL, Sooka A, Burger A, Van der Haar L. Microbial contamination of traditional medicinal plants sold at the Faraday muthi market, Johannesburg, South Africa. South African J Bot. 2014;94:95-100. https://doi.org/10.1016/j.sajb.2014.06.002.

62. World Health Organization (WHO). Prioritization of pathogens to guide discovery, research, and development of new antibiotics for drug-resistant bacterial infections, including tuberculosis. World Health Organization; 2017. Available from: https://apps.who.int/iris/bitstream/handle/ 10665/311820/WHO-EMP-IAU-2017.12-eng.pdf

63. World Health Organization (WHO). A global priority list of antibioticresistant bacteria to guide research, discovery, and development of new antibiotics. 2018. Available from: https://www.who.int/medicines/publi cations/WHO-PPL-Short_Summary_25Feb-ET_NM_WHO.pdf

64. Poudel A, Hathcock T, Butaye P, Kang Y, Price S, Macklin K, et al. Multidrugresistant Escherichia coli, Klebsiella pneumoniae, and Staphylococcus spp. in houseflies and blowflies from farms and their environmental settings. Int J Environ Res Public Health. 2019;16(19):3583. Available from: https://pubmed.ncbi.nlm.nih.gov/31557837/

65. Paulson JR, Mahmoud IY, Al-Musharafi SK, Al-Bahry SN. Antibioticresistant bacteria in the environment as bio-indicators of pollution. Open Biotechnol J. 2016;10(1). Available from: https://pubmed.ncbi.nlm.nih. gov/21237506/

66. Destoumieux-Garzón D, Mavingui P, Boetsch G, Boissier J, Darriet F, Duboz $\mathrm{P}$, et al. The one health concept: 10 years old and a long road ahead. Front Vet Sci. 2018:5:14. https://doi.org/10.3389/fvets.2018.00014.

67. Sharmin M, Nur IT, Acharjee M, Munshi SK, Noor R. Microbiological profiling and the demonstration of in vitro anti-bacterial traits of the major oral herbal medicines used in Dhaka Metropolis. Springerplus. 2014;3(1):739. Available from: https://pubmed.ncbi.nlm.nih.gov/25674469/

68. McCarthy M. Woman dies after infection with bacteria resistant to all antibiotics available in the US. British Medical Journal Publishing Group; 2017. Available from: https://scholar.google.com/scholar?hl=en\&as_sdt=0\% 2C5\&q=McCarthy\%2C+M.+\%282017\%29.+Woman+dies+after+infec tion+with+bacteria+resistant+to+all+antibiotics+available+in+US.+ British+Medical+Journal+Publishing+Group.\&btnG=\#d=gs_cit\&u=\% 2Fscholar\%3Fq\%3Dinfo\%3AEq

69. Aliberti S, Cilloniz C, Chalmers JD, Zanaboni AM, Cosentini R, Tarsia P, et al. Multidrug-resistant pathogens in hospitalized patients coming from the community with pneumonia: a European perspective. Thorax. 2013;68(11):997-9. https://doi.org/10.1136/thoraxjnl-2013-203384.

70. World Health Organization (WHO). WHO guidelines for assessing the quality of herbal medicines with reference to contaminants and residues. World Health Organization; 2007. Available from: https://apps.who.int/ iris/handle/10665/43510

71. World Health Organization (WHO). Guidelines for assessing the quality of herbal medicines with reference to contaminants and residues. Geneva: World Health Organization; 2007. 2007.

72. Brown JC, Jiang X. Prevalence of antibiotic-resistant bacteria in herbal products. J Food Prot. 2008;71(7):1486-90. https://doi.org/10.4315/0362028x-71.7.1486

73. Mashak Z, Tavakoli-Far B. Antimicrobial resistance properties of Staphylococcus aureus isolates from powdered packaged medicinal plants and bottled herbal distillates. 2020. doi:https://doi.org/10.21203/rs.3.rs$116659 / \mathrm{v} 1$

74. Breurec S, Guessennd N, Timinouni M, Le TTH, Cao V, Ngandjio A, et al. Klebsiella pneumoniae resistant to third-generation cephalosporins in 
five African and two Vietnamese major towns: multiclonal population structure with two major international clonal groups, CG15 and CG258. Clin Microbiol Infect. 2013;19(4):349-55.

75. World Health Organization. The selection and use of essential medicines: report of the WHO Expert Committee, 2015 (including the 19th WHO Model List of Essential Medicines and the 5th WHO Model List of Essential Medicines for Children). Vol. 994. World Health Organization; 2015. Available from: https://www.sciencedirect.com/science/article/pii/S0032 $579119301063 \#$ bib55

76. World Health Organization (WHO). WHO model list of essential medicines - 22nd list, 2021. Geneva; 2021. Report No.: WHO/MHP/HPS/ EML/2021.02). Available from: file:///C:/Users/ABDUL/Downloads/WHOMHP-HPS-EML-2021.02-eng.pdf

77. Pereira LMP, Phillips M, Ramlal H, Teemul K, Prabhakar P. Third-generation cephalosporin use in a tertiary hospital in Port of Spain, Trinidad: the need for an antibiotic policy. BMC Infect Dis. 2004;4(1):1-7.

78. Klein NC, Cunha BA. Third-generation cephalosporins. Med Clin North Am. 1995;79(4):705-19. Available from: https://www.researchgate.net/ publication/337838339_Third_Generation_Cephalosporins

79. Arumugham VB, Cascella M. Third Generation Cephalosporins. StatPearls. 2020. Available from: https://www.ncbi.nlm.nih.gov/books/NBK549881/

80. Downie L, Armiento R, Subhi R, Kelly J, Clifford V, Duke T. Communityacquired neonatal and infant sepsis in developing countries: efficacy of WHO's currently recommended antibiotics-systematic review and meta-analysis. Arch Dis Child. 2013;98(2):146-54. https://doi.org/10.1136/ archdischild-2012-302033.

81. Qiao J, Zhang Q, Alali WQ, Wang J, Meng L, Xiao Y, et al. Characterization of extended-spectrum $\beta$-lactamases (ESBLs)-producing Salmonella in retail raw chicken carcasses. Int J Food Microbiol. 2017;248:72-81.

82. Lester R, Musicha P, Van Ginneken N, Dramowski A, Hamer DH, Garner P, et al. Prevalence and outcome of bloodstream infections due to thirdgeneration cephalosporin-resistant Enterobacteriaceae in sub-Saharan Africa: a systematic review. J Antimicrob Chemother. 2020;75(3):492-507.

83. Dramowski A, Ong'ayo G, Rehman AM, Whitelaw A, Labi A-K, ObengNkrumah N, et al. Mortality attributable to third-generation cephalosporin resistance in gram-negative bloodstream infections in African hospitals: a multi-site retrospective study. JAC-antimicrobial Resist. 2021;3(1):dlaa130. Available from: https://academic.oup.com/jacamr/artic le/3/1/dlaa130/6104122

84. Tack B, Vanaenrode J, Verbakel JY, Toelen J, Jacobs J. Invasive non-typhoidal Salmonella infections in sub-Saharan Africa: a systematic review on antimicrobial resistance and treatment. BMC Med. 2020;18(1):1-22. https://doi.org/10.1186/s12916-020-01652-4.

85. Feasey NA, Dougan G, Kingsley RA, Heyderman RS, Gordon MA. Invasive non-typhoidal salmonella disease: an emerging and neglected tropical disease in Africa. Lancet. 2012;379(9835):2489-99. https://doi.org/10. 1016/S0140-6736(11)61752-2.

86. Ko W-C, Paterson DL, Sagnimeni AJ, Hansen DS, Von Gottberg A, Mohapatra S, et al. Community-acquired Klebsiella pneumoniae bacteremia: global differences in clinical patterns. Emerg Infect Dis. 2002;8(2):160. https://doi.org/10.3201/eid0802.010025.

87. Pfeifer Y, Cullik A, Witte W. Resistance to cephalosporins and carbapenems in Gram-negative bacterial pathogens. Int J Med Microbiol. 2010;300(6):371-9. https://doi.org/10.1016/j.jimm.2010.04.005.

88. Ward PML, Fasitsas S, Katz SE. Inhibition, resistance development, and increased antibiotic and antimicrobial resistance caused by nutraceuticals. J Food Prot. 2002;65(3):528-33. https://doi.org/10.4315/0362-028x65.3.528.

89. Pallett A, Hand K. Complicated urinary tract infections: practical solutions for the treatment of multiresistant Gram-negative bacteria. J Antimicrob Chemother. 2010;65(suppl_3):iii25-33. doi:https://doi.org/10.1093/jac/ dkq298

\section{Publisher's Note}

Springer Nature remains neutral with regard to jurisdictional claims in published maps and institutional affiliations.

Ready to submit your research? Choose BMC and benefit from:

- fast, convenient online submission

- thorough peer review by experienced researchers in your field

- rapid publication on acceptance

- support for research data, including large and complex data types

- gold Open Access which fosters wider collaboration and increased citations

- maximum visibility for your research: over $100 \mathrm{M}$ website views per year

At BMC, research is always in progress.

Learn more biomedcentral.com/submissions 